November 1999 - NREL/TP-500-26969

\title{
Analysis of Wind Power Ancillary Services \\ Characteristics with German 250-MW Wind Data
}

\author{
Bernhard Ernst
}

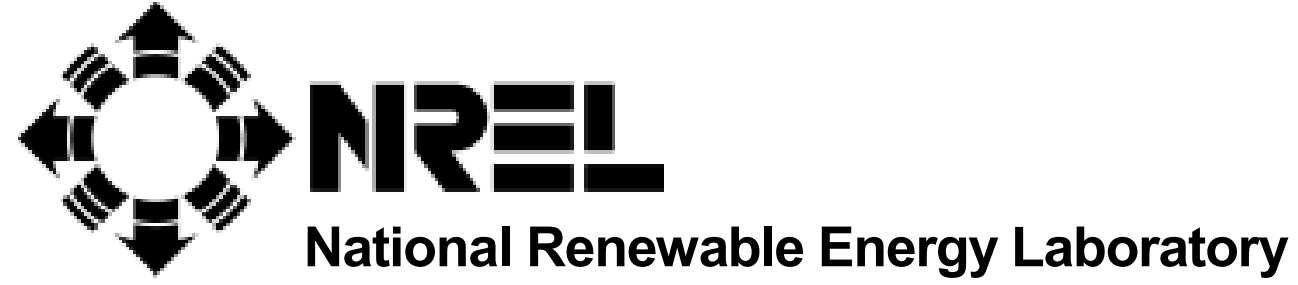

1617 Cole Boulevard

Golden, Colorado 80401-3393

NREL is a U.S. Department of Energy Laboratory

Operated by Midwest Research Institute $\bullet$ Battelle $\bullet$ Bechtel

Contract No. DE-AC36-99-G010337 
November 1999 • NREL/TP-500-26969

\section{Analysis of Wind Power Ancillary Services Characteristics with German 250-MW Wind Data}

\section{Bernhard Ernst}

Prepared under Task No. WE992390

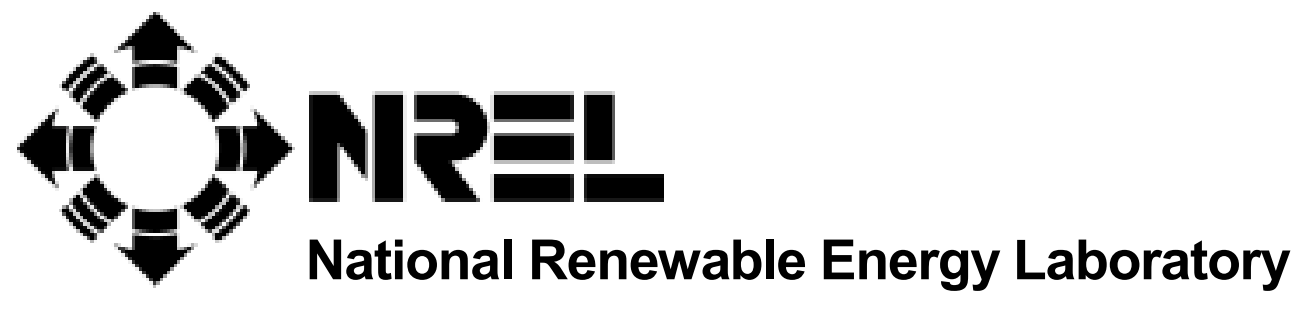

1617 Cole Boulevard

Golden, Colorado 80401-3393

NREL is a U.S. Department of Energy Laboratory

Operated by Midwest Research Institute • Battelle • Bechtel

Contract No. DE-AC36-99-G010337 


\title{
NOTICE
}

This report was prepared as an account of work sponsored by an agency of the United States government. Neither the United States government nor any agency thereof, nor any of their employees, makes any warranty, express or implied, or assumes any legal liability or responsibility for the accuracy, completeness, or usefulness of any information, apparatus, product, or process disclosed, or represents that its use would not infringe privately owned rights. Reference herein to any specific commercial product, process, or service by trade name, trademark, manufacturer, or otherwise does not necessarily constitute or imply its endorsement, recommendation, or favoring by the United States government or any agency thereof. The views and opinions of authors expressed herein do not necessarily state or reflect those of the United States government or any agency thereof.

Available electronically at http://www.doe.gov/bridge

Available for a processing fee to U.S. Department of Energy and its contractors, in paper, from:

\author{
U.S. Department of Energy \\ Office of Scientific and Technical Information \\ P.O. Box 62 \\ Oak Ridge, TN 37831-0062 \\ phone: 865.576 .8401 \\ fax: 865.576.5728 \\ email: reports@adonis.osti.gov
}

Available for sale to the public, in paper, from:

U.S. Department of Commerce

National Technical Information Service

5285 Port Royal Road

Springfield, VA 22161

phone: 800.553.6847

fax:703.605.6900

email: orders@ntis.fedworld.gov

online ordering: http://www.ntis.gov/ordering.htm 


\section{Abstract}

Short-term power fluctuations from wind farms may affect interconnected grid operating costs and stability. With the increasing availability of wind power worldwide, power fluctuations have become a concern for some utilities. Under electric industry restructuring in the United States, the impact of these fluctuations will be evaluated by examining provisions and costs of ancillary services for wind power. However, the magnitude of the impact and the effect of aggregation of multiple wind turbines are not well quantified because of a lack of actual wind farm power data. This paper analyzes individual wind turbine and aggregate power output data from the German "250 Megawatt Wind" data project. Data from as many as 175 turbines were examined. Most of the turbines are located in Northern Germany within a 120,000 square kilometer area. Electric system load following and regulation impacts are examined as a function of the number of wind turbines and turbine spacing to quantify the impacts of aggregation. The results show a significant decrease in the system regulation burden with increasing number of wind turbines, even if the wind turbines are in close proximity. Fluctuations of average power in time intervals ranging from a few seconds to five minutes are examined to help define needs for future wind farm data measurement efforts. 


\section{Table of Contents}

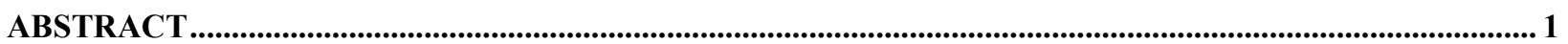

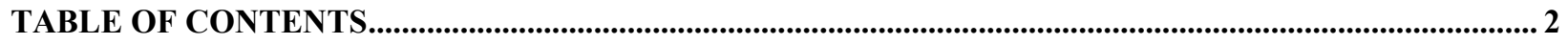

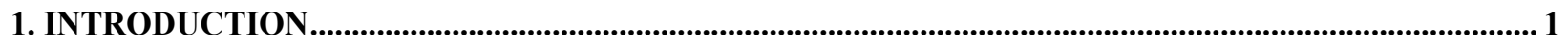

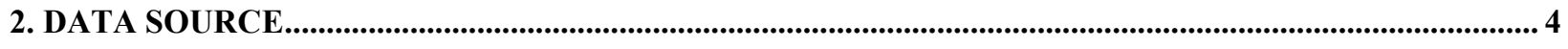

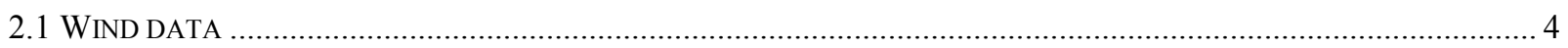

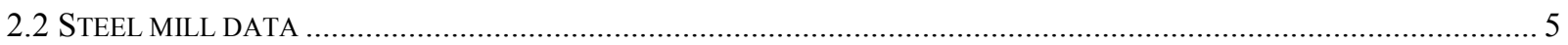

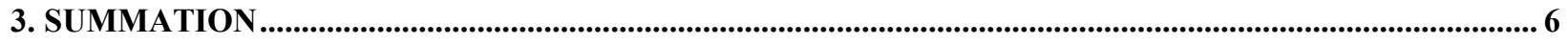

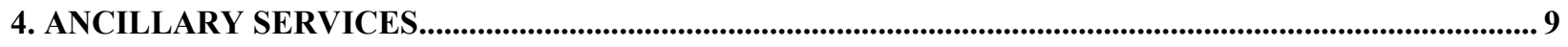

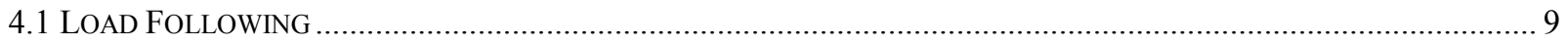

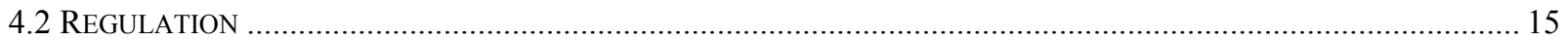

5. CORRELATION OF OUTPUT POWER BETWEEN WIND TURBINES ................................................. 22

6. COMPARISON OF A STEEL MILL WITH A WIND PLANT ........................................................................ 24

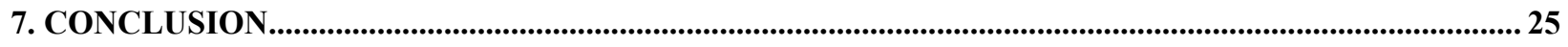

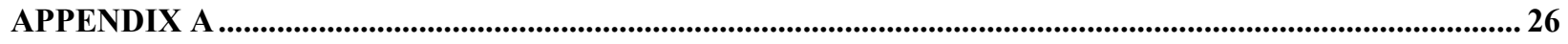

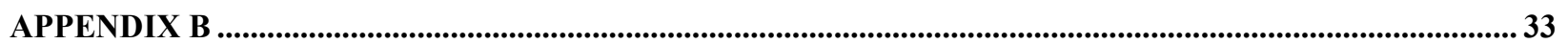

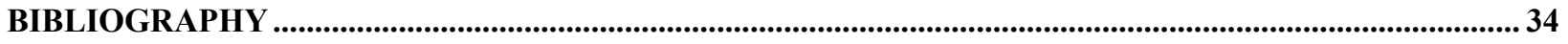




\section{Introduction}

The application of wind energy worldwide has increased rapidly during the past 15 years. In the United States, 1500 megawatts (MW) of capacity was installed in California in the late 1980s and a tax credit program stimulated substantial new wind capacity in many of the states. Minnesota, Iowa, Texas, California, and Wyoming have either developed or are currently developing new wind capacity. Denmark, Germany and more recently, Spain also encouraged an increase in wind energy with various forms of public support. This European trend, which started in the early 1990s, has continued to present. As of April 1999, more than 10,000 MW of capacity had been installed worldwide and the capacity is expected to continue growing during the next few years.

As the application of wind power increases, the ability to integrate significant levels of wind power in the existing grid becomes more important. And because wind power has to compete with other kinds of generation plants, the quality of the electricity is also an important issue. Because of the intermittent nature of wind, the quality of the electricity is mostly affected by power fluctuations that can occur for short periods of time, such as a few seconds or minutes, or periods of time as long as a couple of hours. Ancillary services provided by utility companies can help ensure the quality of the electricity. These services can be defined as "those services that are necessary to support the transmission of capacity and energy from resources to loads while maintaining reliable operation of the transmission system in accordance with good utility practice." Wind turbine (WT) operators are mainly interested in two of the ancillary services: regulation and load following. Regulation can compensate for second-to-second and minute-to-minute power fluctuations, while load following maintains sufficient generation to match hourly demand trends. Wind turbine operators must either provide or purchase these services, usually from the local utility, to connect the wind turbines to the electric power grid.

A third ancillary service, voltage control, can be provided by injecting or absorbing reactive power into the grid. Turbines with electronic power converters may be able to provide voltage control. In this case, the wind plant operator could sell this service to the utility.

The magnitude of the burden to the grid caused by large-scale wind power plants has not yet been well quantified. For this report, I used power output data from the German "250 MW Wind" data project to analyze the ancillary services for individual turbines as well as the aggregated power output from all turbines within the monitoring program. Furthermore, I analyzed the effects of turbine spacing from the ancillary services viewpoint and examined how operators can benefit from a large number of turbines and their spatial spread. 


\section{Data Source}

\subsection{Wind data}

\section{Data Base and Data Processing}

The German Federal Ministry of Economics and Technology is promoting the use of wind energy with the 250-MW Wind Program. The Institut für Solare Energieversorgungstechnik (Institute for Solar Energy Supply Technology [ISET]) in Kassel has been commissioned with the accompanying Wissenschaftliches Meß- und Evaluierungsprogramm (Scientific Measurement and Evaluation Program [WMEP]). This program acquires statistically relevant data on the practical use of WTs.

The two main sources for relevant data are a log book for all WTs in the 250 MW Wind Program and a specific remote measurement network with data acquisition units at selected WT sites.

\section{WMEP Remote Data Acquisition Network}

At 230 selected sites, data loggers and wind measurement equipment were installed to complement the data acquired in log books. Data loggers are connected to the central database system at ISET via modem and the public telephone network. Ten Hertz $(\mathrm{Hz})$ raw data can be transmitted on-line for any period without disturbing the statistical long-term measurement. The following signals are measured at a $10 \mathrm{~Hz}$ sample rate:

- Electrical power

- Status of the grid connection

- Wind speed

- Wind direction

Five minute mean values and 22 additional statistical measures are derived from this raw data. The results are stored as Long-Term Measurements in separate day files. Each day file contains information about:

- $\quad$ Long-term data (288 five minute intervals)

- $\quad$ Binned wind speed (19 intervals)

- Special event data (started only by pre-set triggers)

- Diagnostics of the measurement equipment

- Measurement parameters.

The day files are transferred to ISET and loaded into the central database system every night.

In addition, extreme situations can be registered by Special Event Measurements. These measurements are started only when pre-set trigger values are exceeded.

\section{Central Database}

All the project data acquired by the WMEP, including all measurement data, are managed by a database system at ISET. Most of the software used was custom-made at ISET. It serves the following purposes:

- Support in program management

- Control of data acquisition and remote data acquisition network

- Checking and handling of incoming data

- Basic data processing tasks

- Preparation of data for specific investigations 
- Making data accessible to the Renewable Energy Information System on the Internet (REISI)

A relational system is used to ensure that the structure of the database can be adapted to changing requirements during the course of the project. Several additions to the data acquisition instrumentation had been integrated into the original system.

\section{Data Flow, Remote Data Acquisition Network Control}

A central database system and supplementing software for controlling the remote data acquisition network are located at ISET. From ISET, the daily transfer of measurement data is automatically initiated and controlled. The incoming data is checked for completion and plausibility and then stored. Missing data is automatically requested the following day. The activation of new measurement sites and the deactivation of faulty data loggers is also controlled by the database. After the raw data is checked, it is further processed by calculating mean and other values for each day, month, or year.

\subsection{Steel mill data}

Oak Ridge National Laboratory provided the sample steel mill data from a midsize utility used in the Chapter 6. 


\section{Summation}

For the analysis of regulation and load following the first step was to calculate the aggregated power of turbines. I analyzed data from 1998 because this was an average wind year in Germany. As mentioned in Chapter 2, there are 230 turbines within the WMEP equipped with data loggers that measure power, wind speed and wind direction. Because of faulty sensors or damages caused by lightning, ice, or overvoltage, data were not available for all the sites for that year. In 1998, 176 turbines had an availability factor of $90 \%$ or more, which is the threshold I used to select the turbine data for this report.

To get the aggregated power I added the available signals for each 5-minute interval and counted the number of turbines and their rated power. For cases in which the power signals were not available, I used the wind speed and measured power curve to calculate the power signal. Using this method I derived an average availability of $97 \%$.

For the aggregation I chose different groups of turbines:

Group 1:

All of the 176 turbines located throughout the country, totaling $46 \mathrm{MW}$ rated power. This group is typical for Europe, especially Denmark and Germany (See Figure 3-1).

Group 2:

Three locations with 8, 4, and 5 turbines. These locations are 160 kilometers $(\mathrm{km})$ to $370 \mathrm{~km}$ apart, which is typical of wind plants in the United States (See Figure 3-2).

\section{Group 3:}

Fifteen turbines close together to simulate one or two wind plants in a limited area of about $30 \mathrm{~km}$ in diameter (See Figure 3-3).

Group 4-8:

Respectively eight turbines each to simulate one or two wind plants in a limited area (approximately 30 $\mathrm{km}$ ) in different constellations with different distances between the turbines. 


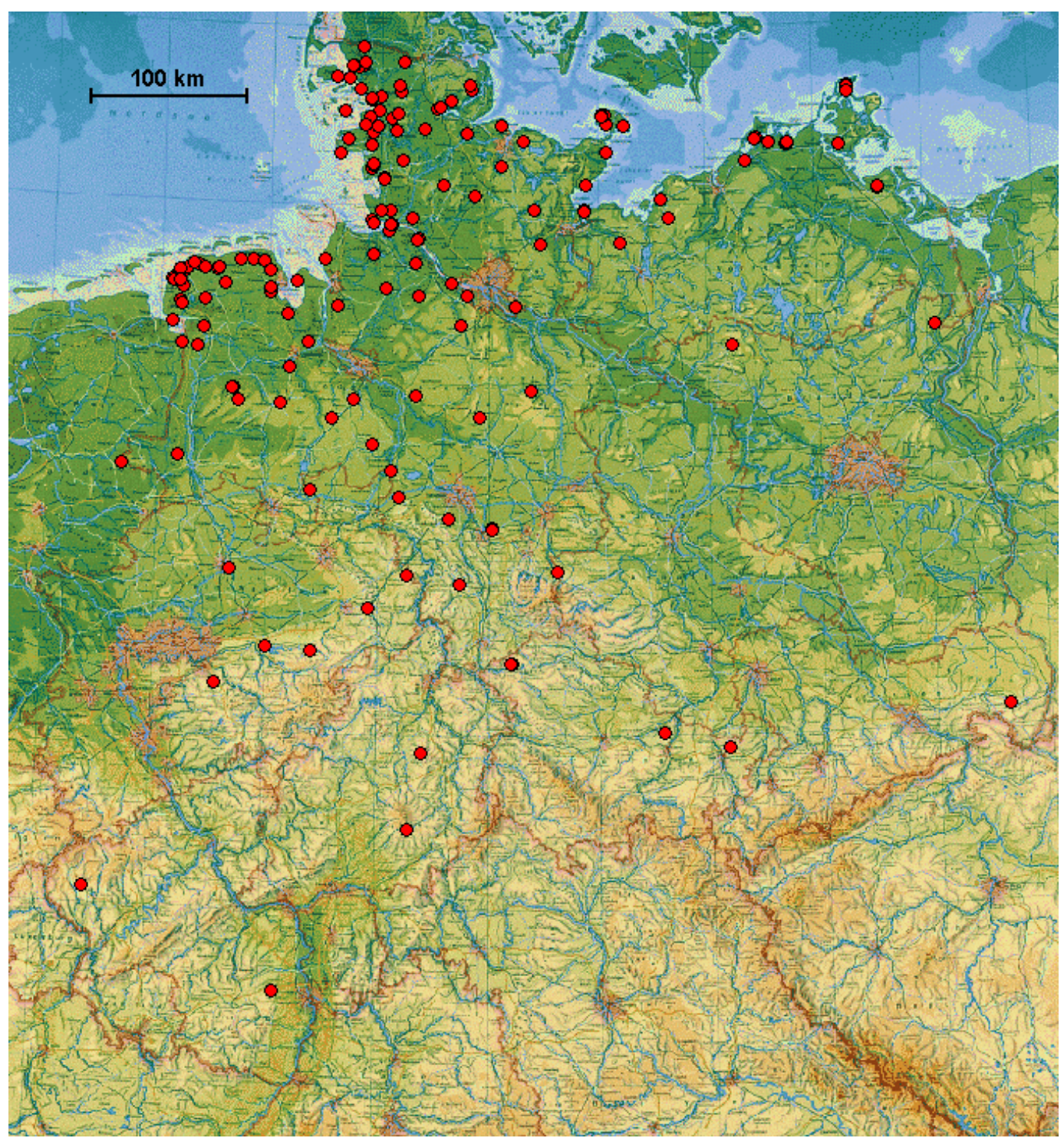

Figure 3-1. Group 1 


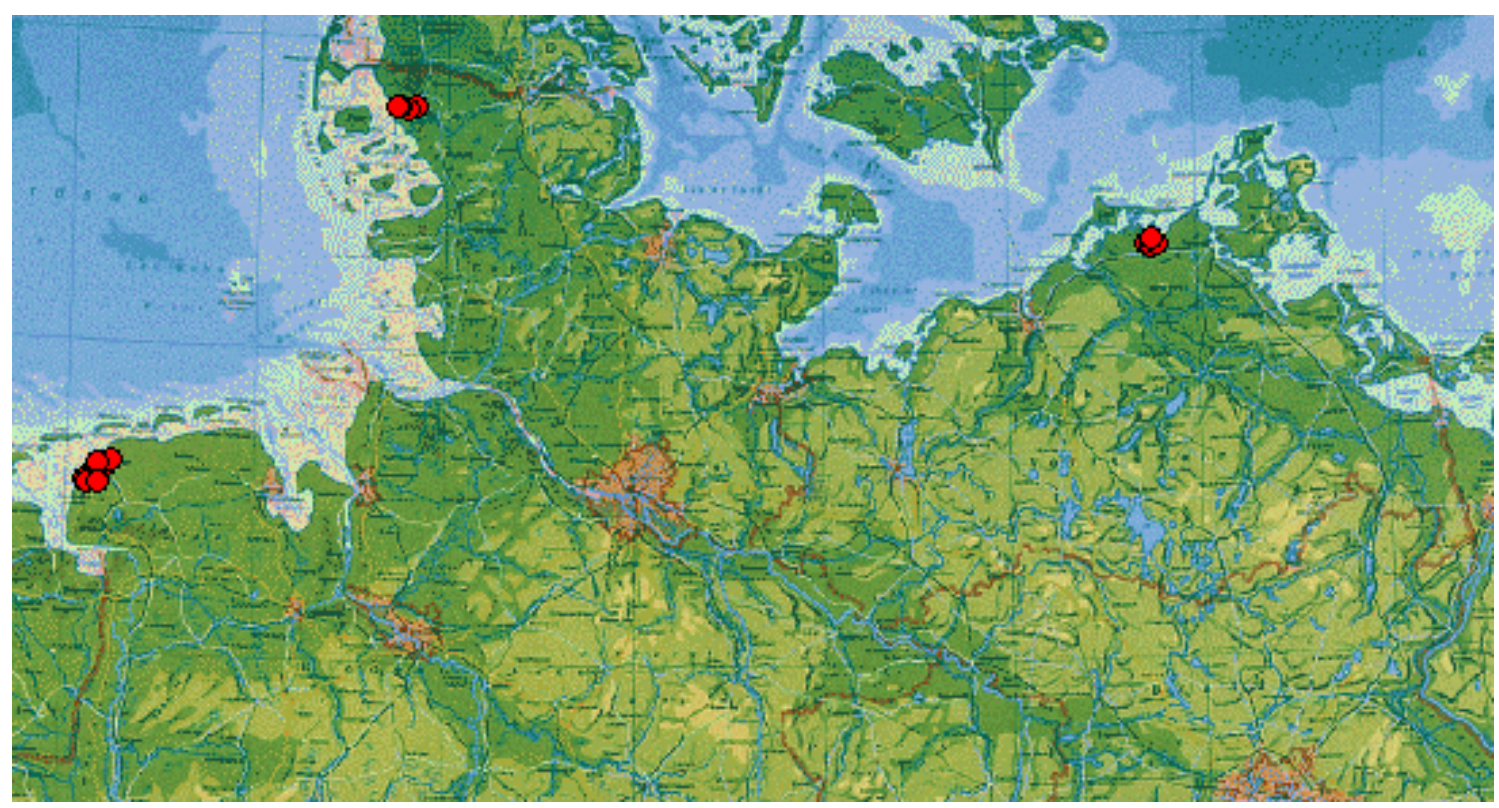

Figure 3-2. Group 2

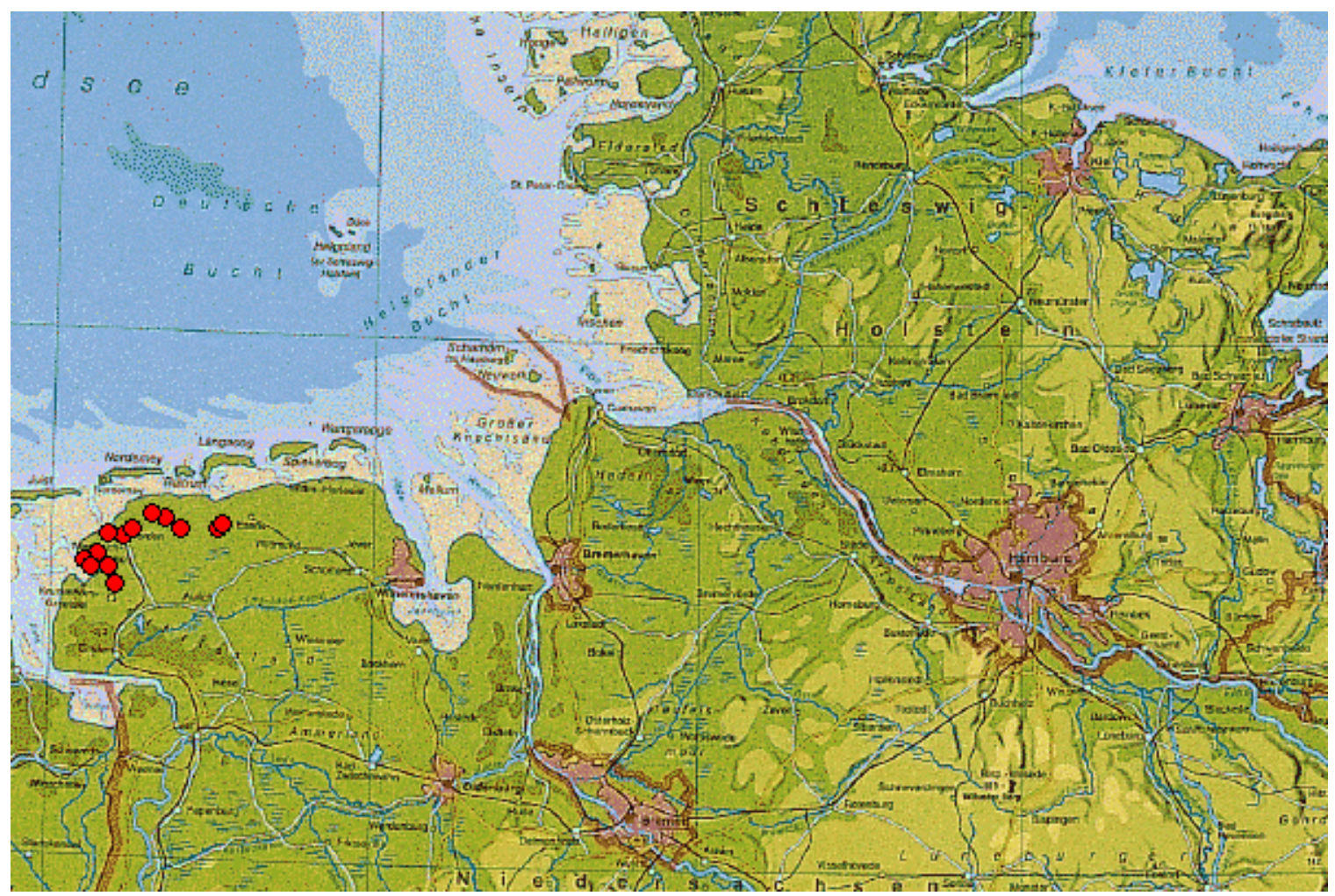

Figure 3-3. Group 3 


\section{Ancillary Services}

The term "ancillary services" refers to power system services other than the simple provision of energy and real power. These services may include functions such as scheduling and dispatch, load following, regulation, reliability reserve, and voltage control. In the past, these services were provided by the local utility. But with the restructuring of the electricity market, they have been separated from generation and transmission. In the future, it is likely that generation providers, transmission providers, and even the customers will trade these services.

The total costs of these services average about $10 \%$ of the generation and transmission costs. However, in some control areas they may be as much as $25 \%$.

The following five ancillary services are relevant to wind energy.

- Regulation: Maintenance of the minute-to-minute generation/load balance

- Load following: Maintenance of the hour-to-hour generation/load balance

- Reactive supply and voltage control from generation: Injection and absorption of reactive power from generators to control transmission voltages

- Frequency responding/spinning reserve: Immediate response to contingencies and frequency deviation

- Supplemental reserve: Response to restore generation/load balance within 10 minutes of a generation or transmission contingency.

Wind turbine operators must either buy regulation or provide it with a conventional dispatchable generator, such as a hydropower plant or a fossil fuel-powered generator. Operators may also buy or sell load following services depending on the match of WT output and load demand.

\section{Reactive Supply and Voltage Control from Generation}

As more new turbines are equipped with electronic power converters, it may be possible for a wind plant operator to sell the voltage control service by injection or absorption of reactive power. Of course, it would then be necessary for the utility to provide a signal for the demand for reactive power.

\section{Frequency Responding/Spinning Reserve}

Variable speed controlled machines could use the momentum of the rotor and the generator to respond to frequency deviation and provide spinning reserve. The kinetic energy stored in the rotor is about two seconds at rated power. These turbines could provide stability by increasing or decreasing the power a little for a few seconds.

\section{Supplemental Reserve}

Although the output of a single turbine can fail abruptly because of broken components or cut-out because of high wind speed, a wind plant never stops or increases substantially within seconds. It takes at least a few minutes for the total power of a wind plant to come down. Thus, a wind plant operator may require less supplemental reserve with wind turbines than with other generation devices.

\subsection{Load Following}

Load following tracks the hourly trends in power output and the hourly changes in power demand for a 24 hour period within a control area. I extended the time frame to examine 1 to 4 hour trends to determine if during 24 hours the wind power correlated with power demand. I used the 5-minute average data of the aggregated power of Groups 1 to 3 for this analysis and performed linear regressions on data sets with 
time frames ranging from 1 hour to 4 hours. The linear regression finds a straight line that fits best for the given data set. Only the slope of the linear regression is of interest. Using different time frames helps determine if the short trends continue for a longer time. (Short time frames [1 hour] show the momentary changes while longer-time frame regressions [2 to 4 hours] show longer trends.)

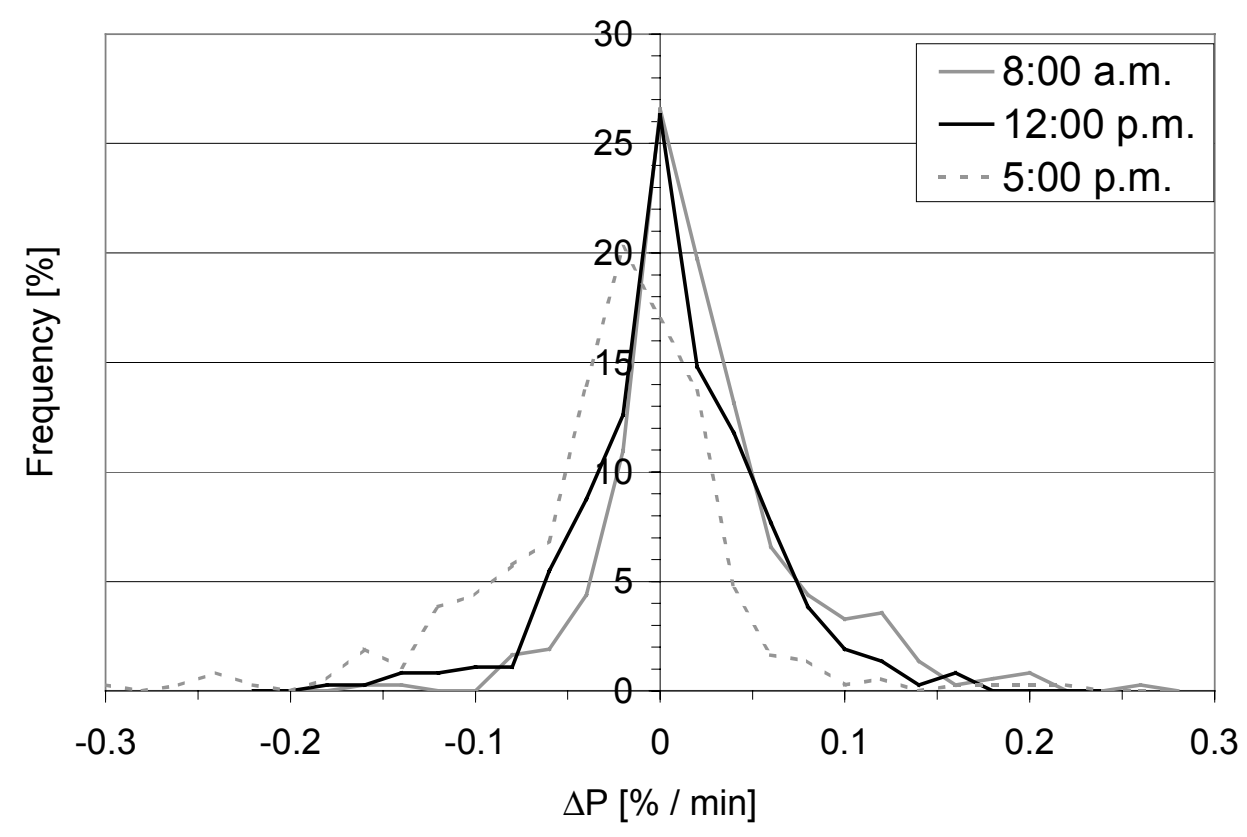

Figure 4-1. Distribution of the slope of a 1-hour regression for the total output of 176 turbines (Group 1)

I divided the resulting slope values for every hour into classes of $0.1 \%$ of rated power per 5 minutes (or $0.02 \%$ per minute) and tabulated for every half hour to see if there were significant trends at specific times of the day. For example, for the 1-hour regression at $12 \mathrm{p} . \mathrm{m}$. in the summer, I looked at the slope values from 12 p.m. to 1 p.m. of every summer day and counted how often each class occurred.

Several different graphs identify how often each slope occurs and display the results of this calculation for summer and the winter seasons combined. Figure 4-1 shows the distribution of the slope at 8:00 a.m., 12:00 p.m., and 5:00 p.m. for Group 1. The difference between the morning and the afternoon is evident in this graph. For a.m. hours, the graph shows more positive slopes and for p.m. hours more negative slopes. This suggests that in the morning the wind generation levels are more likely to increase than decrease, and in the afternoon, the opposite is true. Although this graph is useful for identifying how often each slope occurs, it permits visualization of only a few specific times. 


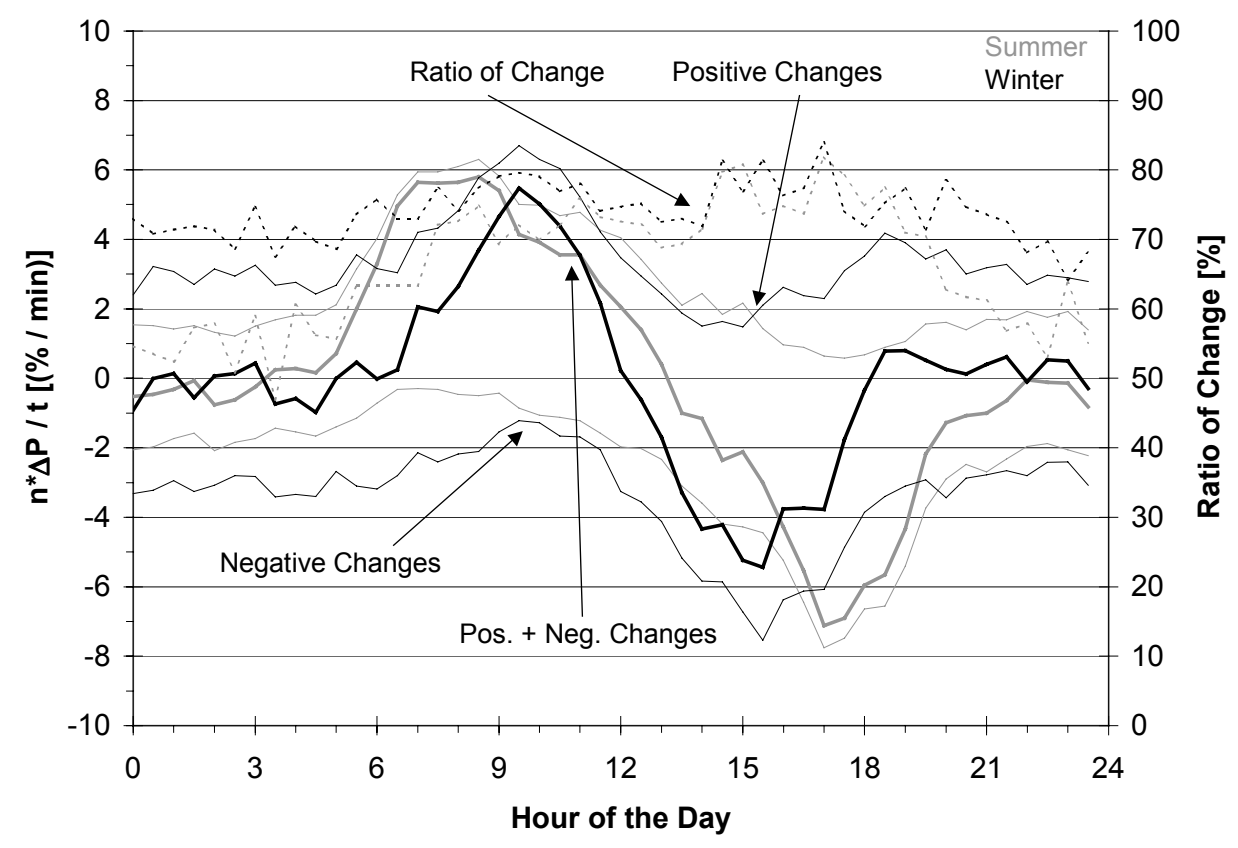

Figure 4-2. Number of occurrences weighted with the slope of the 1-hour regression for the total output of 176 turbines (Group 1)

To display data from an entire day, a weighted slope graph is used in Figure 4-2. In this graph, I multiplied the slope values by the number of occurrences for each 30 minutes time frame throughout the day. This equates one event of $0.1 \% / \mathrm{min}$ as two events of $0.05 \% / \mathrm{min}$. The following definitions provide further explanation of the lines in Figures 4-2 through 4-6.

\section{Ratio of Change}

This line shows how often the slope is not equal to zero.

\section{Positive + Negative Changes}

This line shows the resulting weighted slope of positive and negative slopes. A positive slope nullifies a negative one and vice versa. A slope of $0 \% / \mathrm{min}$ does not count.

\section{Positive Changes and Negative Changes}

These lines show the weighted regressions for positive and negative slopes separately. This is more informative than the sum because it determines if the sum shows a clear trend, or just a difference in positive and negative slopes.

In Figures 4-3 to 4-6 the number of events is multiplied by the square of the slope values. One event of $0.1 \% / \mathrm{min}$ thus counts for as much as four events of $0.05 \% / \mathrm{min}$. This intensifies large changes that may have a bigger impact on the utility. 


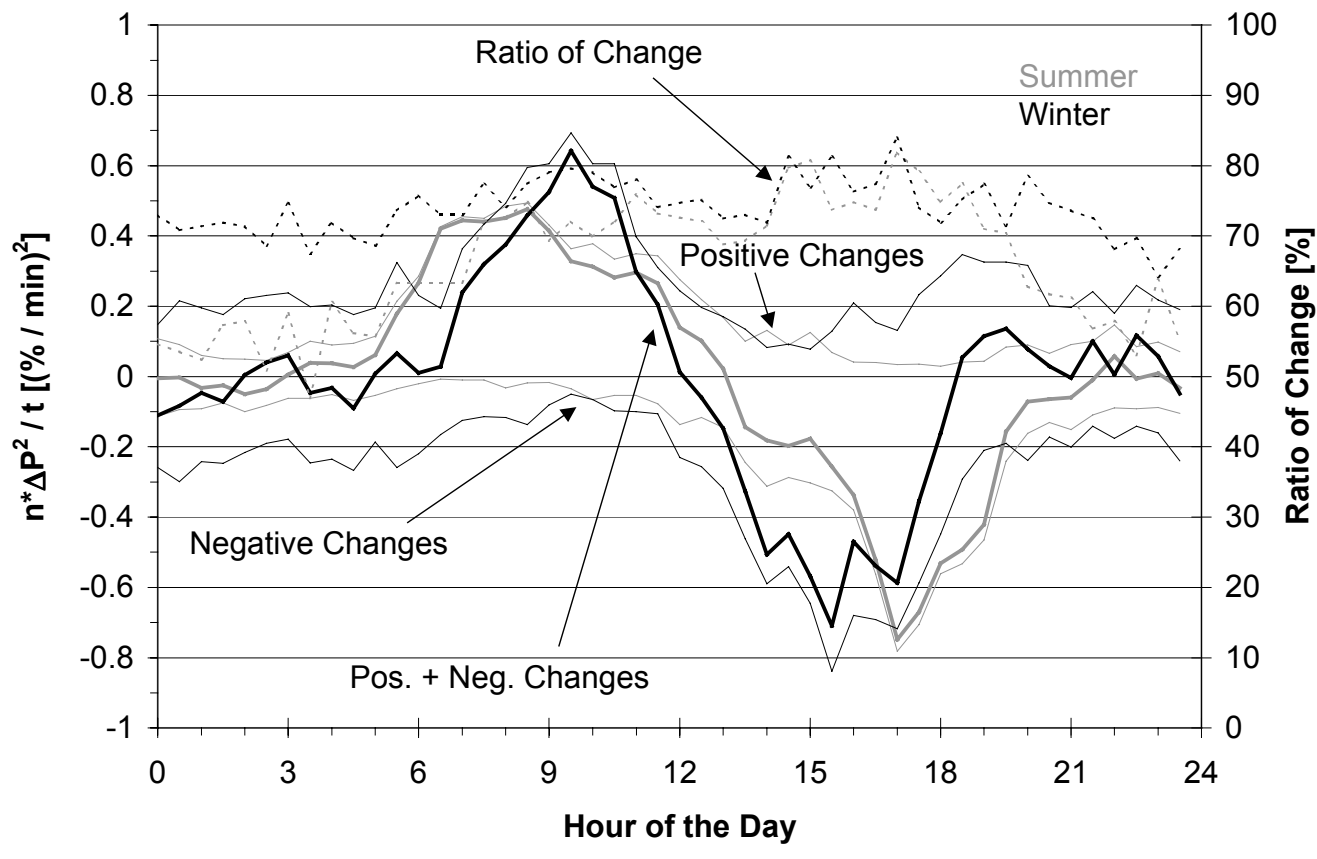

Figure 4-3. Number of occurrences weighted with the square of the slope of the one-hour
regression for the total output of 176 turbines (Group 1)

The analysis shows that between $15 \%$ and $50 \%$ of the time there is essentially no change. (The slope is in a band between $-0.01 \% / \mathrm{min}$ and $0.01 \% / \mathrm{min}$ which is interpreted as zero.) If changes occur, they will be very small. The greatest change occurs at Group 1 is $0.24 \% / \mathrm{min}$ or $14.4 \% / \mathrm{h}$; this occurs only once. For Groups 2 and 3, changes are more likely and greater in value because of fewer turbines.

Although the wind in Germany is mostly driven by weather fronts, a daily pattern caused by the sun is also evident. Therefore, I divided the year in two parts. The first part, from October to March, has fast winds and little sunshine. The second part, from April to September, has lower average wind speeds and sunshine is more likely.

During the winter months, a daily pattern is evident. Most of the changes, including the positive and negative changes follow the daily load pattern, which actually helps the utility. During the summer months, there are almost no days with a decrease in the morning and an increase in the afternoon. This pattern is most distinctive for the Group 1 because it has many turbines located in a large area. This analysis does not show the order of changes. It is not apparent whether an increase is followed by another increase within the next time frame. To investigate longer trends, the 2- and 4-hour regressions (shown in Figure 4-4) must be studied. These trends are much smoother because of the longer time frame. However, they show that the trend of the on 1-regression is continued for a longer period. 


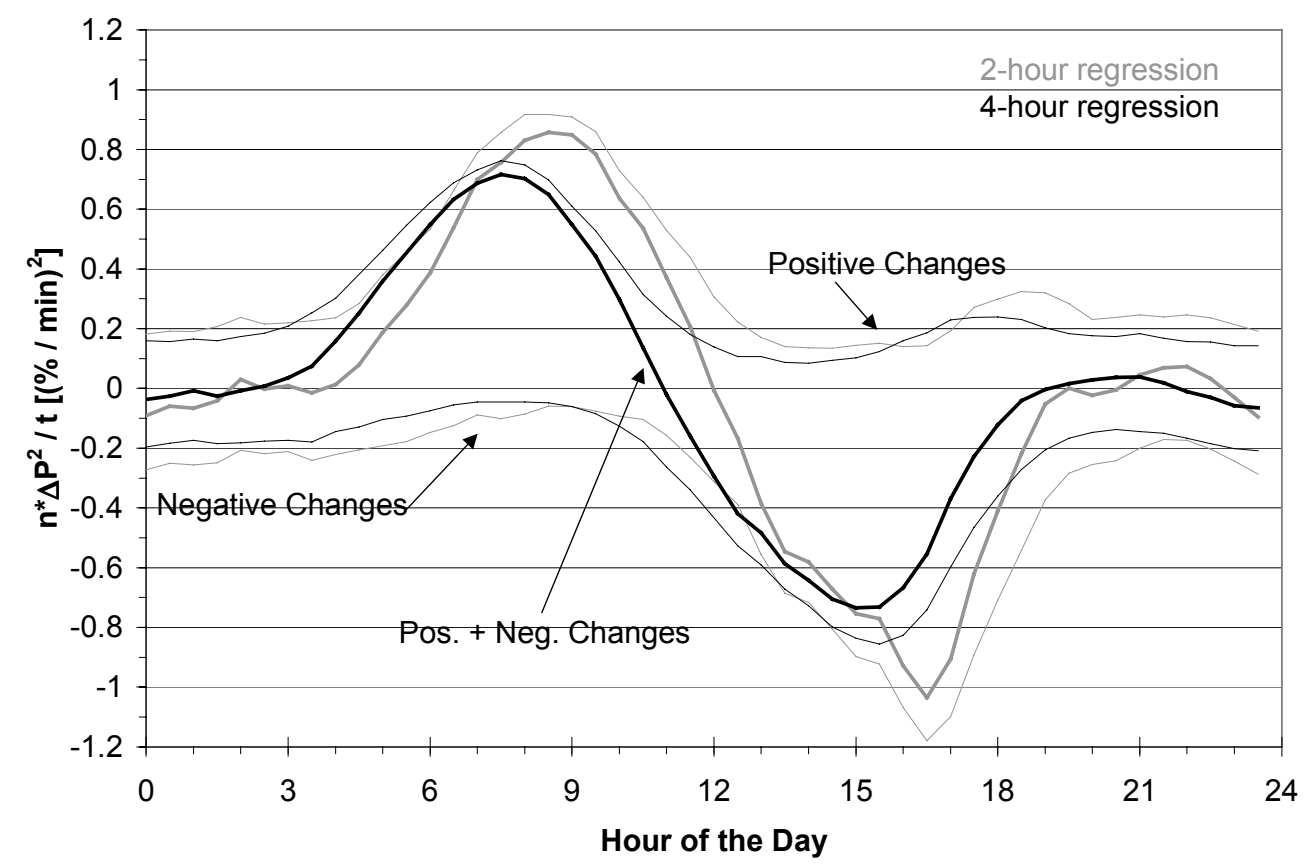

Figure 4-4. Number of occurrences weighted with the square of the slope of the 2-hour and 4-hour regression for the total output of 176 turbines (Group 1)

Although Groups 2 and 3 have almost the same number of turbines, there is a big difference between their power-output patterns. This difference could be because the turbines of Group 2 are spread over three locations along the German coastline while the turbines of Group 3 are located within a small area. However, the 4-hour regressions indicate that although Group 3 experiences more fluctuations within a few hours, it exhibits the same daily pattern found in Groups 1 and 2 (see Figures 4-5 and 4-6). 


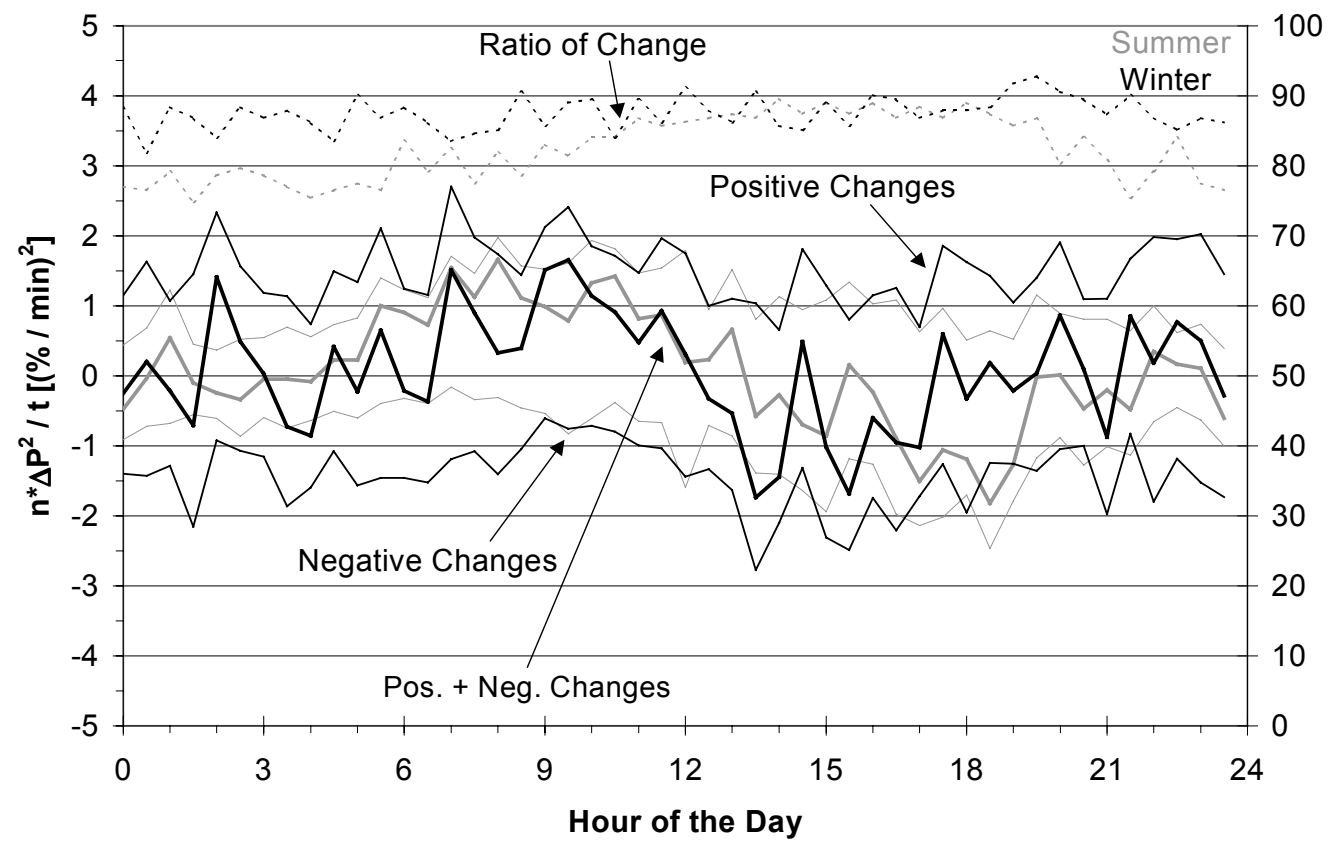

Figure 4-5. Number of occurrences weighted with the square of the slope of 1-hour regression for the total output of 17 turbines (Group 2)

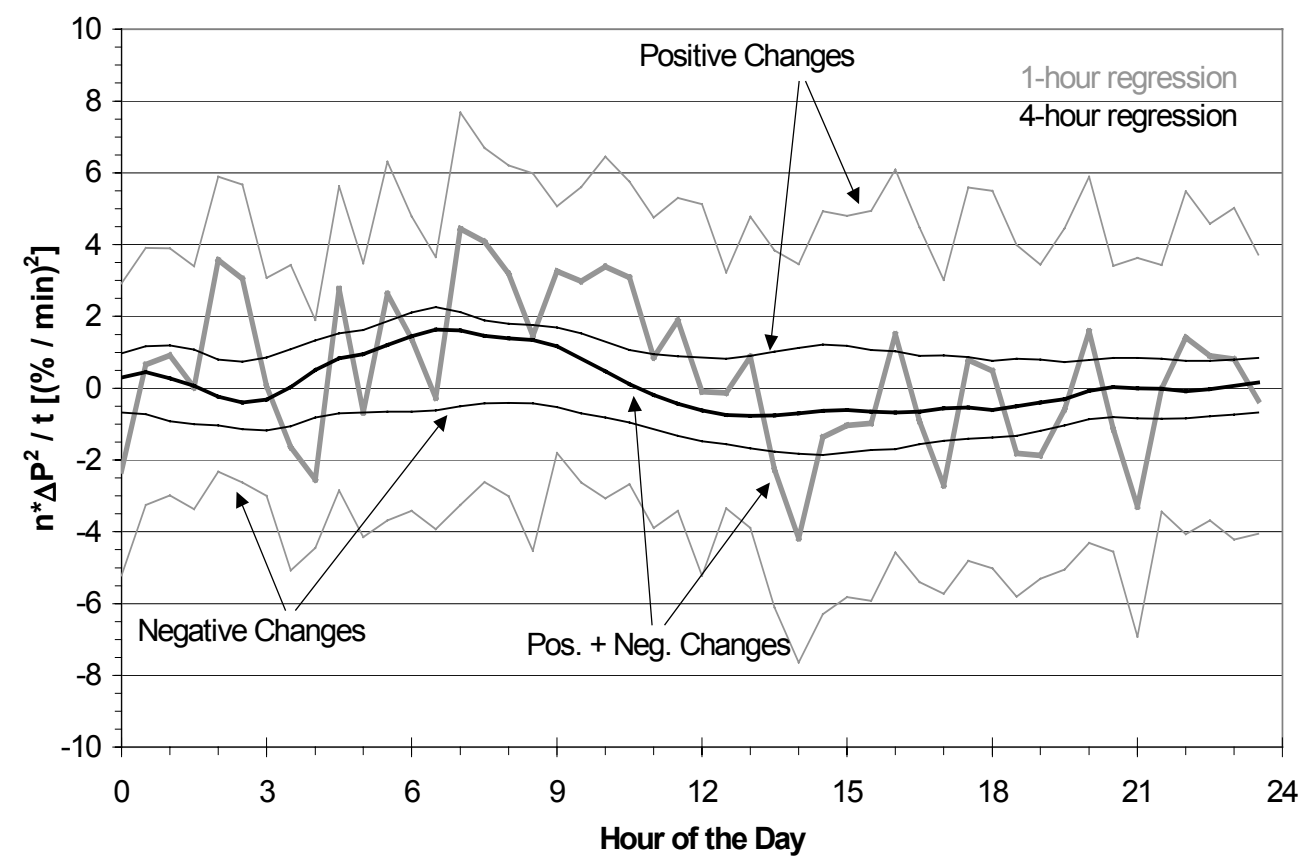

Figure 4-6. Number of occurrences weighted with the square of the slope of 1-hour regression for the total output of 15 turbines (Group 3) 


\subsection{Regulation}

There are several ways to separate regulation from load following. One convenient method for after-thefact analysis is to use a 60 -minute rolling average ( 30 minutes before and 30 minutes after the hour). Regulation is the difference between the actual signal and the rolling average. The standard deviation of the regulation is a good measurement for the regulation burden. This technique has the advantage of providing a smooth transition between measurement periods. The disadvantage of the technique is that because the data must be available for 30 minutes before and 30 minutes after the analysis period, an hour of analysis is lost. This is a serious disadvantage if only a short data set is available.

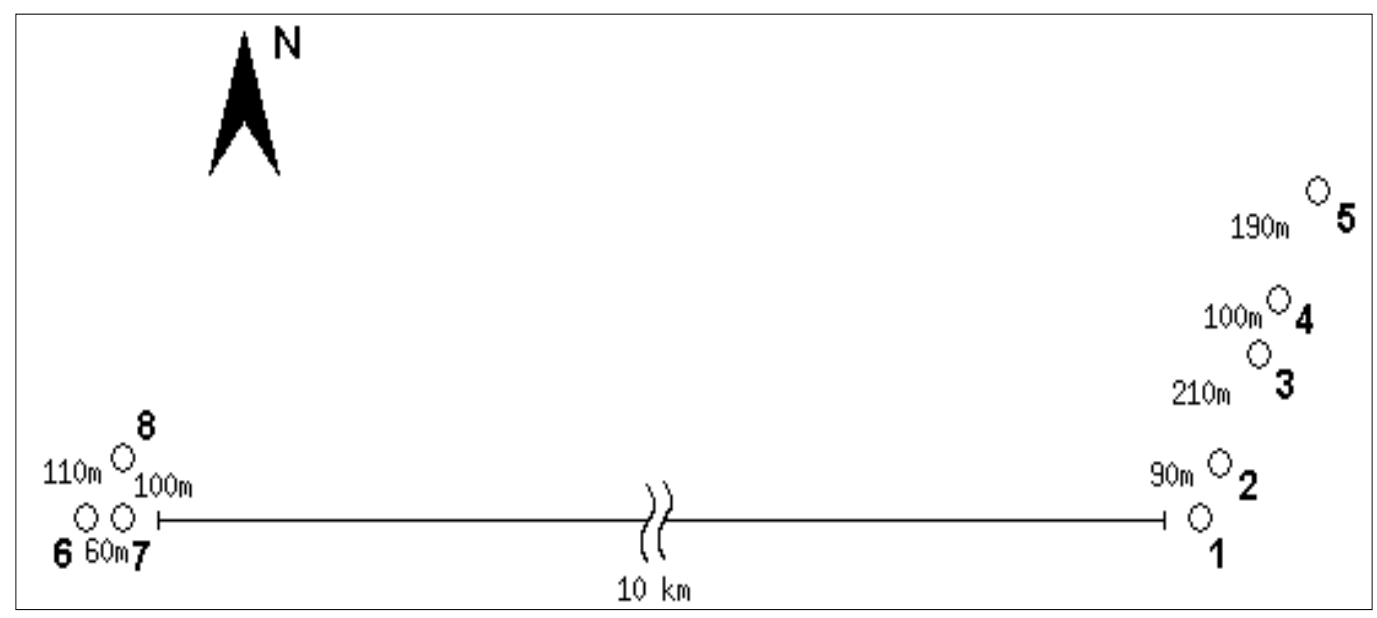

Figure 4-7. Map of turbines from site 1

Currently, utilities examine minute-to-minute fluctuations; however, they may examine 30-second average data in the future to catch faster fluctuations. Therefore, I used 30-second average data for these calculations. Although only 5-minute data is usually stored in the database within the $250 \mathrm{MW}$ Wind project, it is possible to obtain $10 \mathrm{~Hz}$ data online via modem. For this analysis, I retrieved $1310 \mathrm{~Hz}$ data sets with 45-minute to 3-hour lengths and calculated the 30-second average. I retrieved seven sets from a site with eight turbines (see Figure 4-7) and six sets from a site with four turbines (see Figure 4-8, also see Appendix B for details).

Although Groups 2 and 3 have almost the same number of turbines, there is a big difference between their power-output patterns. This difference could be because the turbines of Group 2 are spread over three locations along the German coastline while the turbines of Group 3 are located within a small area. However, the 4-hour regressions indicate that although Group 3 experiences more fluctuations within a few hours, it exhibits the same daily pattern found in Groups 1 and 2 (see Figures 4-5 and 4-6). 


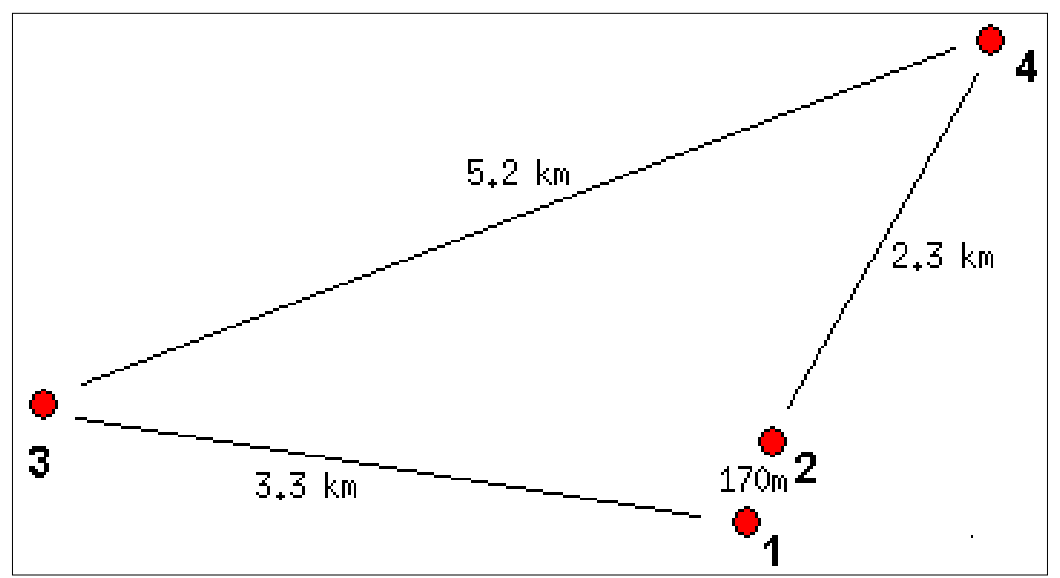

Figure 4-8. Map of turbines from the four-turbine site

The 30-second data sets are typically 1 to 2 hours long. The corresponding 5 -minute data were used to calculate the rolling averages at the start and end of each data set because the data sets were so short. This procedure allowed me to use the whole 30 -second data set for the regulation analysis.

Because the turbines are different in type and size on both sites, their outputs were normalized with respect to each turbine's average power in the data set to eliminate the size bias.

Analyses were carried out for different numbers of turbines and groupings to see the effects on the regulation burden. The calculation was performed for each group with all data sets and an average was taken. Because of different lengths of data sets, a weighted average was derived depending on the length of each data set.

Figure 4-9 shows an example of the regulation analysis. It shows actual power output, rolling average, and the difference for both a single turbine and a group of six turbines. The smoothing effect of the wind plant is easy to see. The regulation is relatively smaller for the wind plant than for the single turbine. To measure the smoothing effect, the ratio between the standard deviation of the regulation for the total output and the sum of the standard deviation of the regulation for the single turbines is calculated. The ratio shows the reduction in regulation burden that results from a grouping of turbines. A lower ratio means a lower relative regulation burden. The ratio for this data set is $50.2 \%$. If the turbine output were uncorrelated, theoretically the ratio should be equal to the square root of $n$ divided by $n$ where $n$ is the number of turbines. In this case, the theoretical ratio should be $40.8 \%$. However, these turbines are closely located in a wind plant, and are not uncorrelated (see Chapter 5 Corelation of Output Power Between Wind Turbines); and their power outputs do not have the same distribution. This explains why the ratio is higher than the theoretical value. 


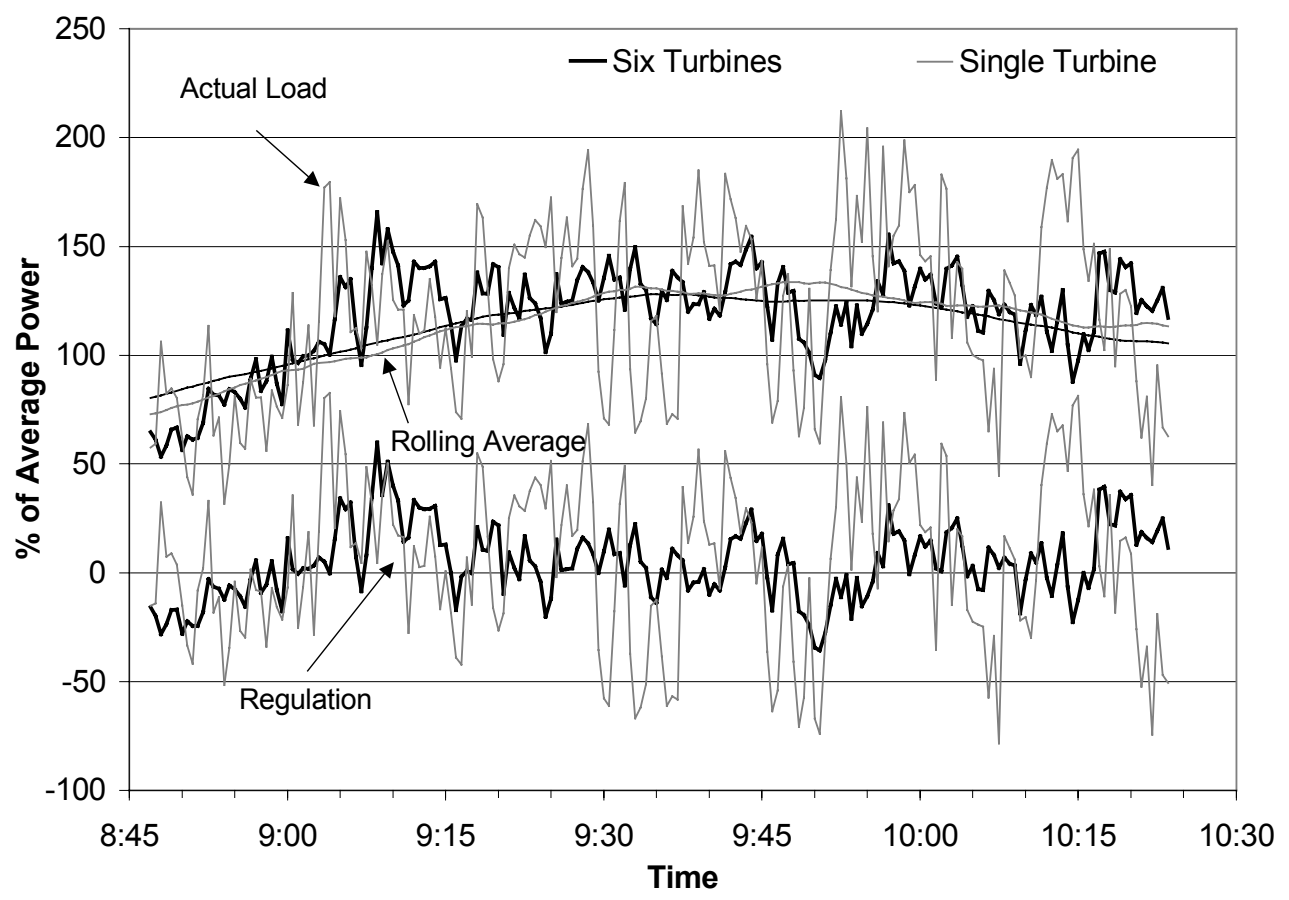

Figure 4-9. Actual power, rolling average and regulation for a wind plant and a single turbine

Table 4-1. Ratio Between the Sum of the Regulation Burden of the Single Turbines and the Regulation Burden of the Aggregated Power for Different Groupings-EighTurbine Site

\begin{tabular}{|c|c|c|c|}
\hline Icon & $\because$ & $\begin{array}{ll} & \ddots \\
0 & \bullet\end{array}$ & \begin{tabular}{|ll} 
& \\
& $\vdots$ \\
0 & $\vdots$
\end{tabular} \\
\hline Grouping & 1 & 2 & 3 \\
\hline Ratio, 30-sec data & 0.449 & 0.523 & 0.534 \\
\hline Ratio, 5-min data & 0.501 & 0.533 & 0.572 \\
\hline Theoretical Ratio & 0.354 & 0.408 & 0.447 \\
\hline
\end{tabular}

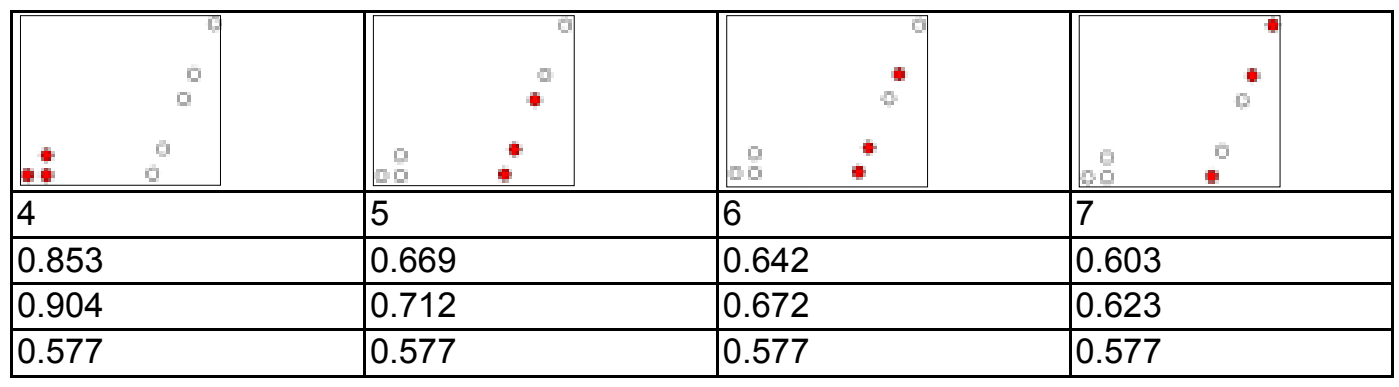


Table 4-2. Ratio between the sum of the regulation burden of the single turbines and the regulation burden of the aggregated power for different constellations at site 2

\begin{tabular}{|c|c|c|c|c|}
\hline \multirow[t]{2}{*}{ Icon } & & & & \\
\hline & - & - $\quad 8$ & 0 & o \\
\hline Grouping & 1 & 2 & 3 & 4 \\
\hline Ratio, 30-sec data & 0.614 & 0.712 & 0.760 & 0.827 \\
\hline Ratio, 5-min data & 0.684 & 0.682 & 0.807 & 0.891 \\
\hline
\end{tabular}

Tables 4-1 and 4-2 display different groupings and the analysis of calculated ratios for the two sites. The filled dots, in the icon, show which turbines were included for the grouping. In groupings one to three, the ratio increases with the decrease in the number of turbines. Groupings four to seven have three turbines each but the distances between turbines increase in each grouping from groupings four to seven. As distance increases there is a decrease in the ratio value.

In group seven, the turbines are spaced $200 \mathrm{~m}(660 \mathrm{ft})$ and $400 \mathrm{~m}(1320 \mathrm{ft})$ apart, which is typical for wind plants with large modern turbines. The ratio is $60 \%$, and the theoretical value is $57 \%$. This trend indicates that closely spacing the turbines (as on a wind farm) does not decrease the benefit of having a large number of turbines. This trend also demonstrates that the correlation of the 30-second average data within a wind plant is not as high as one might expect. When longer average times are analyzed (5minutes in this case), the ratio is still close to the theoretical value. I did the calculation for all of the groupings using 5-minute data to see if I could quantify the ratio with 5-minute data. This quantification is important because, I have 5-minute data from the last few years for over 200 German wind turbines.

The absolute value of the standard deviation of the regulation is a quantum for the regulation burden. However, the cost of regulating the fluctuations has not yet been quantified, because this depends primarily on the utility system where the wind plant is located. Later in the report, I will compared a wind plant with a steel mill to give some perspective on the size of fluctuations of a wind plant (see Chapter 6). 


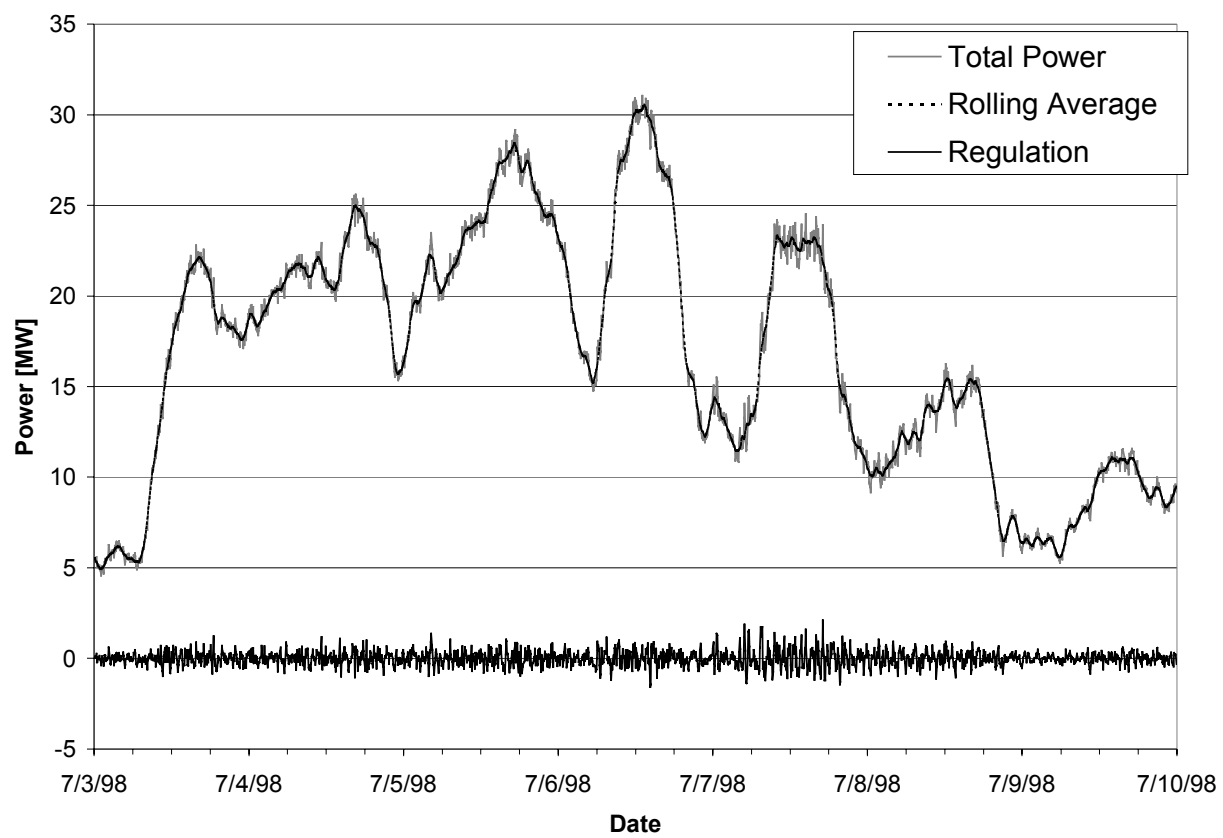

Figure 4-10. Actual power, rolling average and regulation for Group 1

Although the 5-minute data analysis cannot tell us the absolute regulation burden, the resulting ratios display a similar pattern. This finding encouraged me to do more calculations with five-minute data to learn more about the effects of the number of and the distance between turbines. I did the calculation for Groups 1 to 8 for 1998. For Group 1 I did the calculation twice: the first time using the absolute power and the second time using the power output of each wind turbine normalized to its rated power (this step treats the turbines as if they were all the same size). The size of the turbines in Group 1 varies from 30 $\mathrm{kW}$ to $1.5 \mathrm{MW}$. When using absolute power, large turbines have more influence. This makes it appears as though there are fewer turbines. However, with the normalization, the effects of increasing the number of turbines is clearly seen. This trend may prove interesting when the results are transferred to other areas. Figure 4-10 shows the regulation for Group 1 over a period of one week in June which shows that the regulation drops significantly compared to the absolute power of many turbines. The number of turbines, the average distance between the turbines, and the calculated ratio values for Groups 1 to 4 are shown in Table 4-3. The large distance between the turbines in Group 2 seems to indicate that the distance between turbines does not have much influence on the ratio because Group 3 shows almost the same ratio with nearly the same number of turbines standing in one area. 
Table 4-3. Ratio Between the Sum of the Regulation Burden of the Single Turbine and the Regulation Burden of the Aggregated Power for Different Groupings Derived from 5-Minute Data

\begin{tabular}{|l|l|l|l|l|}
\hline Group & $\begin{array}{l}\text { No. of } \\
\text { Turbines }\end{array}$ & Average Distance & Ratio & Theoretical Ratio \\
\hline 1 & 176 & $217.7 \mathrm{~km}$ & $12.4 \%$ With absolute power & $7.5 \%$ \\
\hline 1 & 176 & $217.7 \mathrm{~km}$ & $9.5 \%$ with relative power & $7.5 \%$ \\
\hline 2 & 17 & $\begin{array}{l}3.89 \mathrm{~km} \text { within the turbines, } \\
266 \mathrm{~km} \text { between the turbines }\end{array}$ & $39.80 \%$ & $24.2 \%$ \\
\hline 3 & 15 & $13.1 \mathrm{~km}$ & $40.40 \%$ & $25.8 \%$ \\
\hline 4 & 8 & $13.7 \mathrm{~km}$ & $44.90 \%$ & $35.4 \%$ \\
\hline
\end{tabular}

I used Groups 4 through 8 to see what effect the distance has on the ratio. There are eight turbines in each of these groups. The average distances, the average of the distances from each turbine to all the others, varies between $6 \mathrm{~km}$ and $13 \mathrm{~km}$. This number does not show the actual distance between turbines, but it is best suited for comparing the groups. Figure 4-11 shows the decrease of the ratio with the increase of the average distance. Although none of the groups reaches the theoretical ratio of $35.4 \%$, some of them come close.

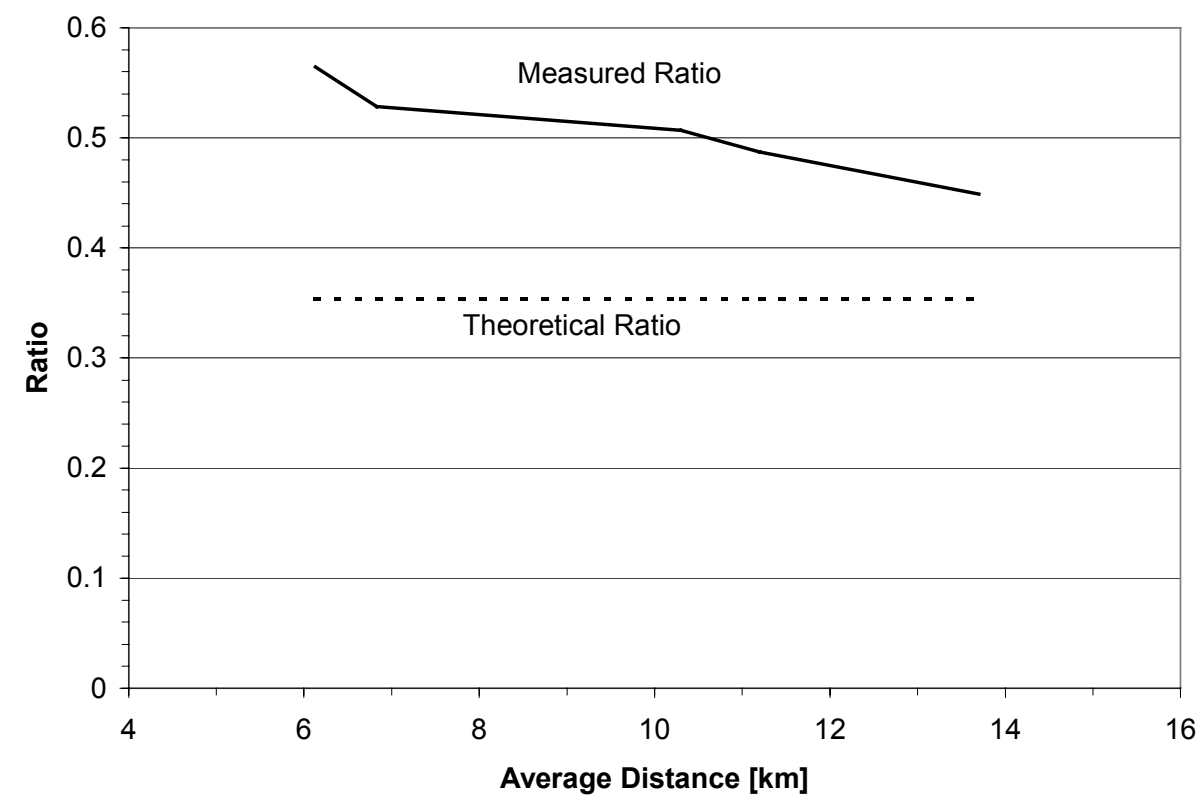

Figure 4-11. Ratio between the sum of the regulation burden of the single turbines and the regulation burden of the aggregated power for eight turbines with different distances

(Group 4 to 8) 
Figure 4-12 shows the distribution of the standard deviation for 179 turbines. I did not analyze which turbine types or which sites are in which range of regulation. It is interesting to note that they are close together. The turbine size or type makes little difference for the regulation burden. However, the distribution may change with a shorter average time, such as a few seconds.

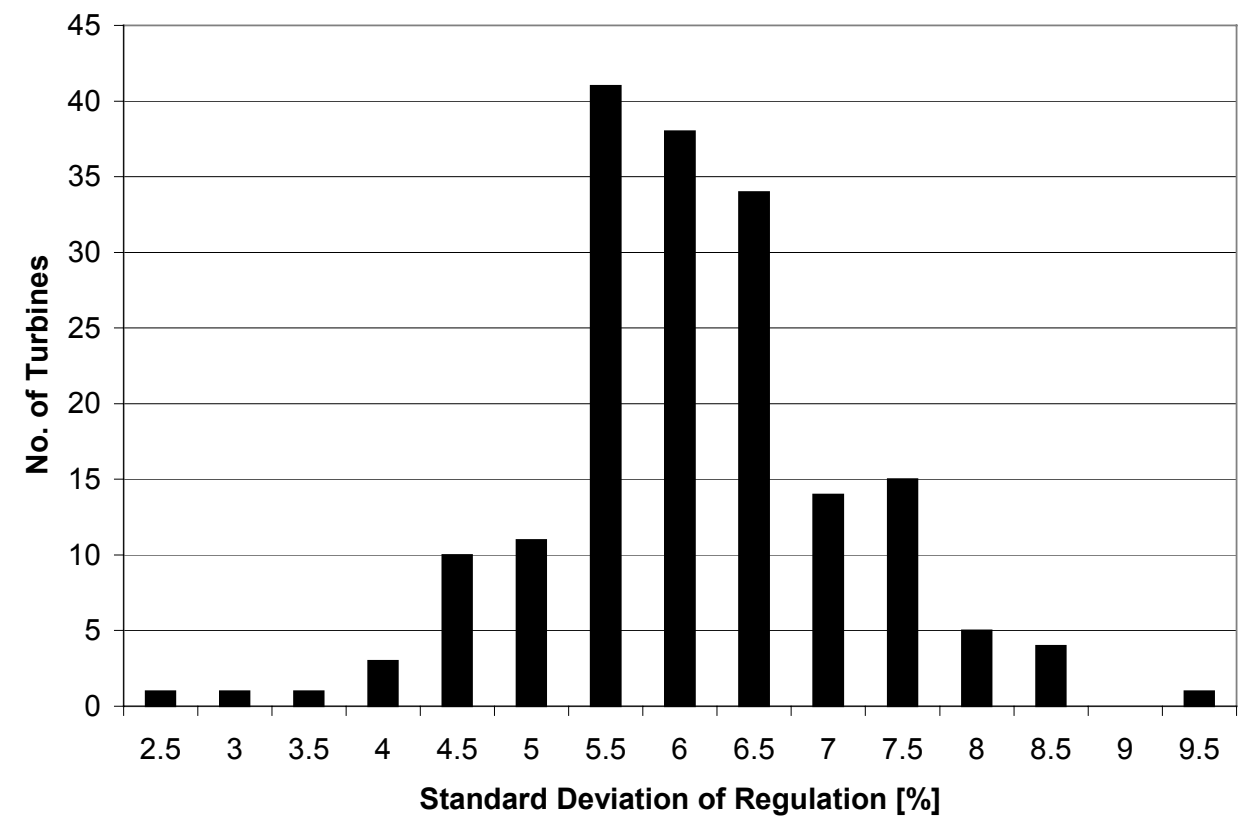

Figure 4-12. Distribution of the standard deviation of regulation for 179 Turbines 


\section{Correlation of output power between Wind Turbines}

As seen in the Section 4.1 and 4.2, greater distance between turbines necessitates fewer ancillary services. This trend is due to the correlation between closely sited wind turbines. The greater the distance between turbines, the less they are correlated. To demonstrate this correlation, I calculate the linear correlation coefficients for different distances. I used the changes in power $\Delta \mathrm{P}$ from one step to the next for this calculation instead of the absolute power. When considering the ancillary services, changes in power is more interesting than the absolute power. Five-minute data from two sites with a high availability were used to investigate the correlation among all wind turbines. The linear correlation coefficient $r$ is the covariance of two signals divided by their standard deviations (Equation 5-1). The resulting correlation coefficient is normalized even if the signals have different orders of magnitude. Therefore, the absolute power data were used in the calculation. If the changes of power at both turbines were always in the same direction, $\mathrm{r}$ would be equal to 1 and the signals are said to be completely positive correlated. If they go always in opposite directions, $r$ is equal to -1 and the signals would be negative correlated. The correlation coefficient $r$ is equal to zero if the signals are totally uncorrelated.

$r=\frac{\sum_{i=1}^{n}\left(\Delta P_{1, i}\right)\left(\Delta P_{2, i}\right)}{\sqrt{\sum_{i=1}^{n}\left(\Delta P_{1, i}\right)^{2}} \sqrt{\sum_{i=1}^{n}\left(\Delta P_{2, i}\right)^{2}}}$

(Equation 5.1)

where $\Delta P_{\mathrm{n}, i}=P_{\mathrm{n}, i}-P_{\mathrm{n}, i-1}$ and $P_{1,0}=P_{2,0}=0$.

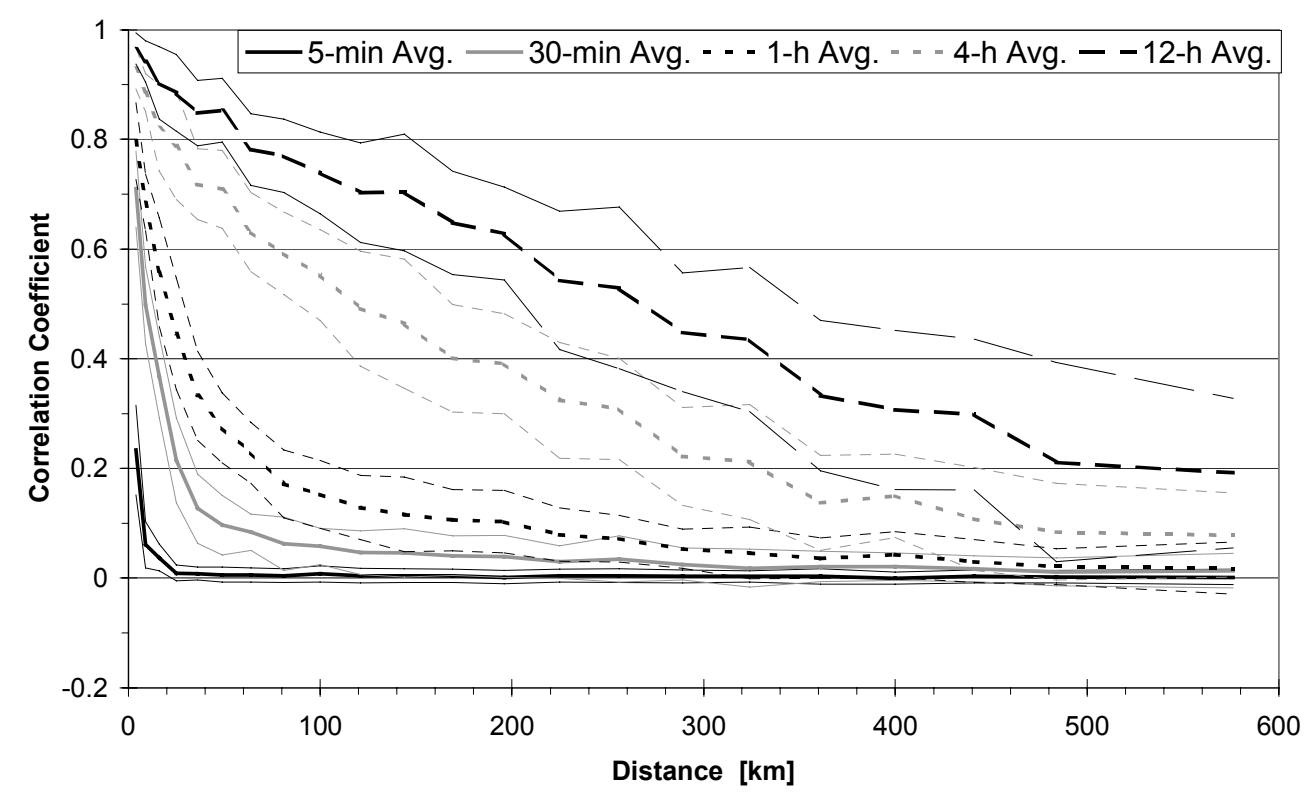

Figure 5-1. Correlation coefficient of $\Delta \mathrm{P}$ for different average times over the distance 
Figure 5-1 shows the results with power averages ranging from as short as 5 minutes to as long as 12 hours. The distances between the compared wind turbines were classified. The thick lines represent the average of these classes, and the thin lines represent the average plus and minus the standard deviation of the class. Because of the length of time required to do these calculations, they were done only for 3 months in the summer and 3 months in the winter. As there is no significant difference between the two seasons, the average for both seasons is displayed.

The correlation coefficient for 5-minute data drops to almost zero after a few kilometers. The regulation calculations using 30-second or 1-minute averages suggest that turbines standing closer would be uncorrelated.

After doing the calculations with 5-minute data, I used the $10 \mathrm{~Hz}$ data sets to examine turbines standing closer together and shorter average times. Figure 5-2 shows the correlation coefficient of two wind turbines at a distance of $170 \mathrm{~m}(560 \mathrm{ft})$ for different average times. As expected, they are highly correlated at an average time of 10 minutes. Up to 1 minute, the correlation coefficient is under 0.2 , which means they are mostly uncorrelated, thus explaining why closely spaced wind turbines can obtain high benefits in terms of regulation burden. Fluctuations up to a few seconds are caused by the wind and by the control mechanism, such as those regulated for variable speed machines.

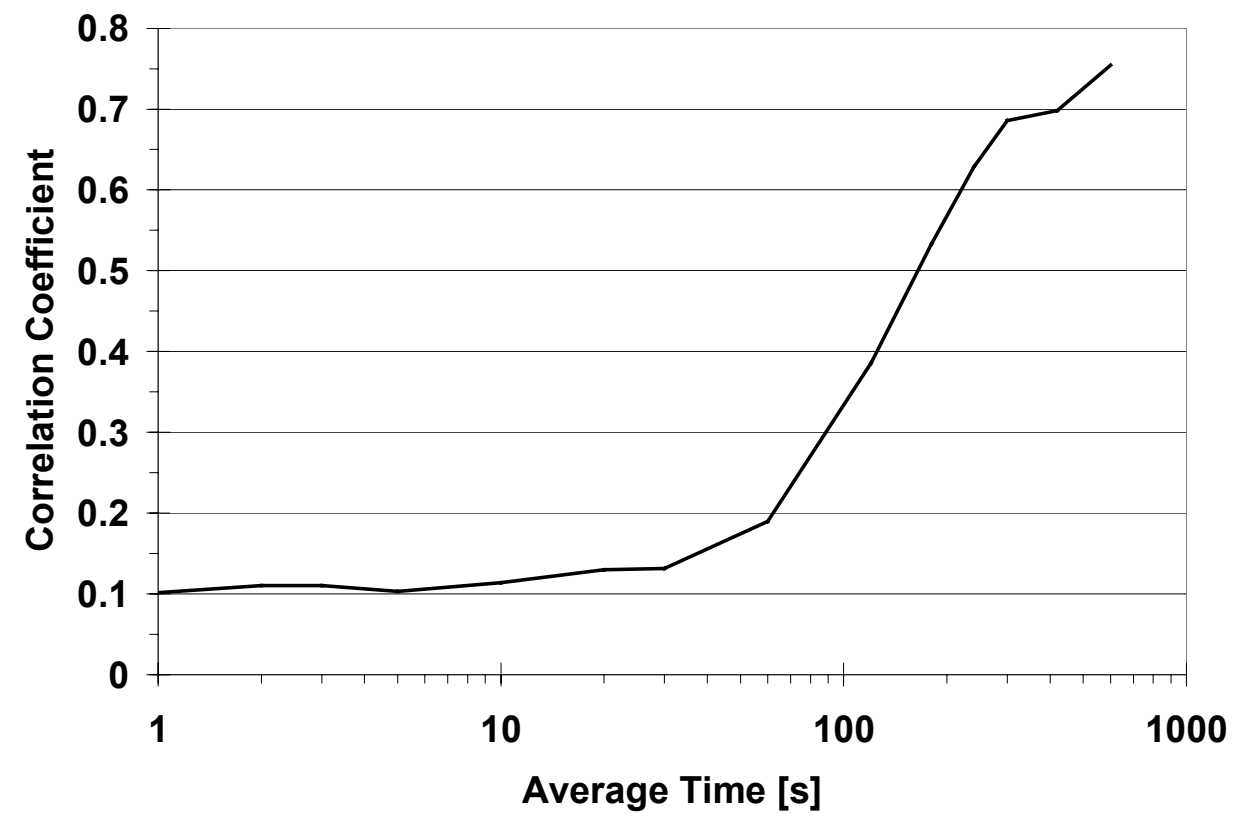

Figure 5-2. Correlation coefficient of $\Delta P$ over the average time for two turbines with a distance of $170 \mathrm{~m}$ 


\section{Comparison of a Steel Mill with a Wind Plant}

The absolute value of the regulation burden caused by a wind plant to a utility is not easy to interpret. It depends on the size of the total load in the utility control area, load characteristics, and the equipment the utility uses for regulation. Thus the costs a wind plant imposes for regulation have not been determined. However, it is possible to compare these costs to costs imposed by other intermittent loads.

I compared load data from a steel mill for one day to load data from a small wind plant with 8 turbines (Group 8) and to the total output of 176 turbines (Group 1). Because of the difference in rated power, all power data were normalized to respective rated power. The output of 176 new turbines would have similar power rating of the steel mill. The capacity factor of the steel mill is $74 \%$ for the chosen day. For the wind plants, I chose a day in January 1998 with about the same average power. I used 5-minute data for both the wind plants and the steel mill.

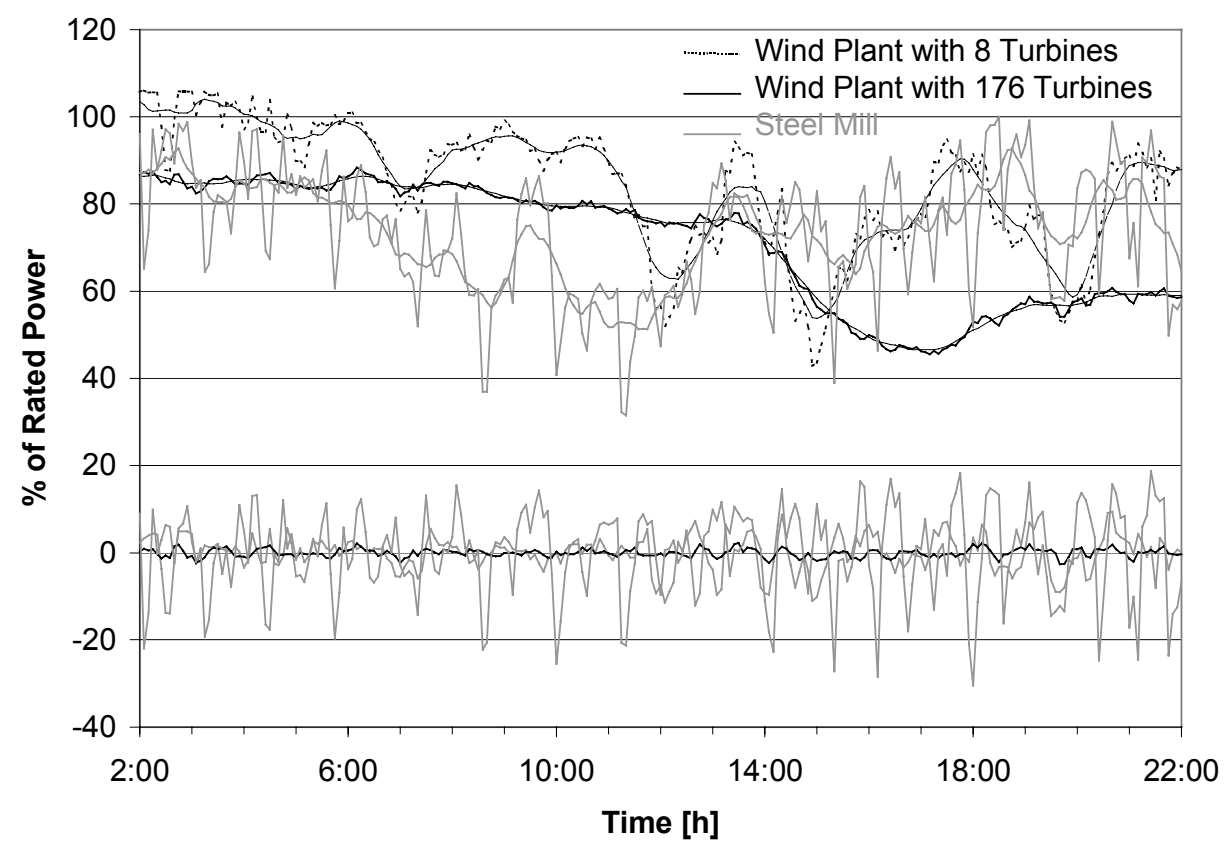

Figure 6-1. Actual power, rolling average, and regulation for two wind plants and a steel mill

Figure 6-1 shows the regulation for the wind plant and the steel mill. As seen in Table 6-1, the standard deviation of the large wind plant, which is the measurement for the regulation burden, is only $10 \%$ of the standard deviation of the steel mill. Obviously, this steel mill is an extreme fluctuating load. The example shows that wind power does not fluctuate as much.

Table 6-1 Comparison of Wind Plant and Steel Mill Load

\begin{tabular}{|l|l|l|}
\hline & Rated Power (MW) & Standard Deviation of Regulation \\
\hline Wind Plant with 8 Turbines & 2.8 & $4.5 \%$ \\
\hline Wind Plant with 176 Turbines & 44.6 & $1.0 \%$ \\
\hline Steel Mill & 107.5 & $9.9 \%$ \\
\hline
\end{tabular}




\section{Conclusion}

Tn this paper, I analyzed wind power data in the context of ancillary services. A large number of turbines and spatial spread may decrease the relative ancillary service requirements substantially. The results for load following are probably unique to the German weather conditions. It is not clear whether wind plants elsewhere would show the same pattern. However, the results of the regulation and the correlation analyses are transferable to other sites.

Correlation analysis of the data shows clear spacing diversity of wind turbine outputs. Wind turbines that are only a couple of kilometers apart are almost totally independent during a short average time like 5 minutes. The data also confirm that, during a shorter time period, wind turbine output within a wind plant is mostly independent. Turbulence within the local wind field accounts for this phenomenon.

Load following analysis suggests that, during a longer time frame, wind generation in Germany has a regular pattern. Available data show that the power level of wind generation generally increases in the morning and decreases in the afternoon. In addition, there is a $15 \%$ to $50 \%$ chance that the power output will not show a trend over an hour. For wind power plants that have patterns similar to those studied here, a wind turbine operator in an ancillary service market would generally expect to be paid for the load following provided by the wind plant. The operator would be billed for the hours that the power output does not follow the system requirements.

Spatial diversity of wind resources helps to reduce regulation burdens of wind power. However, the regulation analysis in this report suggests that the number of turbines have more influence on the regulation burden than the physical separation of wind plants. Comparison of a wind plant to an actual steel mill regulation burden analysis suggests that there are other intermittent loads, that have larger fluctuations than wind plant.

Finally, additional measurements are necessary to analyze big wind farms in the United States. The National Renewable Energy Laboratory (NREL) has begun a collaborative data collection project. Analysis of this data, when it becomes available, will provide important insights to wind plant patterns in the United States. 


\section{Appendix A}

Table A-1. Turbines for summation

\begin{tabular}{|c|c|c|c|c|c|c|c|}
\hline Group & Type & $\begin{array}{l}\text { Rated } \\
\text { Power }\end{array}$ & $\begin{array}{r}\text { Rotor } \\
\text { Diameter }\end{array}$ & $\begin{array}{r}\text { Data } \\
\text { Logger } \\
\text { No. }\end{array}$ & $\begin{array}{r}\text { WMEP } \\
\text { No. }\end{array}$ & $\begin{array}{r}\text { Zip } \\
\text { Code }\end{array}$ & City \\
\hline 1 & Krogmann 15/50 & 50 & 15.0 & 1 & 4000-01 & 36355 & Grebenhain \\
\hline 1 & AN Bonus 150/30 & 150 & 23.0 & 4 & $4000-04$ & 36355 & Grebenhain \\
\hline 1 & Tacke TW 250 & 250 & 24.0 & 6 & $4000-05$ & 36355 & Grebenhain \\
\hline 1 & HSW $250 \mathrm{~T}$ & 250 & 28.5 & 8 & 4000-07 & 36355 & Grebenhain \\
\hline 1 & Enercon E 32 & 280 & 33.0 & 201 & 2046-01 & 58091 & Hagen-Dahl \\
\hline 1 & Lagerwey LW 15/50 & 50 & 15.6 & 301 & 2029-01 & 48157 & Münster \\
\hline 1 & Tacke TW 60 & 60 & 16.9 & 701 & $2017-01$ & 59602 & Rüthen \\
\hline 1 & Nordex N 27/150 & 150 & 27.0 & 901 & 2083-03 & 33184 & Altenbeken \\
\hline 1 & Nordex N 27/150 & 150 & 27.0 & 903 & 2083-01 & 33184 & Altenbeken \\
\hline 1 & DAN mark 22 & 95 & 21.8 & 1001 & $5500-01$ & 78183 & Hüfingen \\
\hline 1 & Enercon E 33 & 280 & 33.0 & 1101 & 5501-01 & 79874 & Breitnau \\
\hline 1 & Lagerwey LW 15/55 & 55 & 15.6 & 1201 & 2022-01 & 32351 & Stemwede \\
\hline 1 & Enercon E 18 & 80 & 19.4 & 1301 & 4003-01 & 34639 & Schwarzenborn \\
\hline 1 & Südwind N 1230 & 30 & 12.5 & 1401 & $4508-01$ & 54597 & Feuerscheid \\
\hline 1 & Micon M 530-175 & 175 & 26.0 & 1701 & 2024-01 & 59469 & Ense \\
\hline 1 & Enercon E 18 & 80 & 19.4 & 1801 & $4523-01$ & 67271 & Neuleiningen \\
\hline 1 & Enercon E 32 & 300 & 32.0 & 10005 & $1011-05$ & 26506 & Norden-Ostermarsch \\
\hline 1 & Enercon E 33 & 300 & 33.0 & 10006 & 1011-06 & 26506 & Norden-Ostermarsch \\
\hline 1 & Lagerwey LW 15/75 & 75 & 15.6 & 10401 & 1079-01 & 31628 & Landesbergen \\
\hline 1 & Micon M 530-250/50 & 250 & 26.0 & 10601 & $1115-01$ & 26802 & Moormerland-Terborg \\
\hline 1 & Enercon E 17 & 80 & 17.2 & 10701 & $1075-01$ & 26901 & Rastdorf \\
\hline 1 & Micon M 530-175 & 175 & 26.0 & 11201 & 1032-01 & 21762 & Osterbruch \\
\hline 1 & Südwind N 1237 & 37 & 12.5 & 11401 & $1078-01$ & 26931 & Elsfleth \\
\hline 1 & Enercon E 18 & 80 & 18.0 & 11501 & $1008-02$ & 26897 & Hilkenbrook \\
\hline 1 & Enercon E 18 & 80 & 18.0 & 11502 & 1008-03 & 26897 & Hilkenbrook \\
\hline 1 & AN Bonus 150/30 & 150 & 23.0 & 11601 & $1065-01$ & 27612 & Loxstedt \\
\hline 1 & AN Bonus 150/30 & 150 & 23.0 & 11801 & 1099-01 & 26316 & Varel \\
\hline 1 & Lagerwey LW 15/75 & 75 & 15.6 & 12101 & 1040-01 & 29593 & Schwienau \\
\hline 1 & AN Bonus 150/30 & 150 & 23.0 & 12201 & 1089-01 & 27246 & Borstel \\
\hline 1 & Krogmann 15/50 & 50 & 15.0 & 12301 & 1024-01 & 29303 & Bergen \\
\hline 1 & AN Bonus 150/30 & 150 & 23.0 & 12401 & 1096-01 & 26203 & Wardenburg \\
\hline 1 & Enercon E 17 & 80 & 17.2 & 12501 & 1031-01 & 21717 & Fredenbeck \\
\hline 1 & Enercon E 17 & 80 & 17.2 & 12601 & 1010-01 & 21279 & Dierstorf \\
\hline 1 & Enercon E 32 & 280 & 32.0 & 13101 & 1019-01 & 31812 & $\begin{array}{l}\text { Bad Pyrmont- } \\
\text { Großenberg }\end{array}$ \\
\hline 1 & Enercon E 32 & 300 & 32.0 & 13301 & 1041-02 & 30974 & Wennigsen \\
\hline 1 & Enercon E 32 & 300 & 32.0 & 13302 & 1041-01 & 30974 & Wennigsen \\
\hline 1 & Lagerwey LW 15/75 & 75 & 15.6 & 13501 & 1056-01 & 38690 & Vienenburg \\
\hline
\end{tabular}




\begin{tabular}{|c|c|c|c|c|c|c|c|}
\hline 1 & Enercon E 17 & 80 & 19.4 & 13601 & $1050-01$ & 26506 & Norden-Süderneuland \\
\hline 1 & Enercon E 17 & 80 & 17.2 & 13801 & $1047-01$ & 26607 & Aurich \\
\hline 1 & Enercon E 32 & 300 & 33.0 & 13901 & $1120-01$ & 26969 & Butjadingen-Tossens \\
\hline 1 & Krogmann 15/50 & 50 & 15.0 & 14001 & $1138-01$ & 27793 & Wildeshausen \\
\hline 1 & $\begin{array}{l}\text { Wind World W } \\
2700 / 150\end{array}$ & 150 & 27.0 & 14101 & $1211-01$ & 26831 & Bunde \\
\hline 1 & Tacke TW 80 & 80 & 21.0 & 14201 & $1231-01$ & 49744 & Geeste-Dalum \\
\hline 1 & DWA $16 / 55$ & 55 & 15.0 & 14301 & 1264-01 & 49843 & Wielen \\
\hline 1 & \begin{tabular}{|l} 
Lagerwey LW \\
$27 / 250$
\end{tabular} & 250 & 27.0 & 14401 & $1179-02$ & 26434 & $\begin{array}{l}\text { Wangerland-Neu } \\
\text { Augustengroden }\end{array}$ \\
\hline 1 & Südwind N 1237 & 37 & 12.5 & 14501 & $1252-01$ & 27308 & Kirchlinteln \\
\hline 1 & Tacke TW 250 & 250 & 26.0 & 14601 & $1265-01$ & 28857 & Syke-Gessel \\
\hline 1 & Vestas V 27/225 & 225 & 27.0 & 14801 & 1181-01 & 21706 & Drochtersen \\
\hline 1 & Seewind 20/110 & 110 & 20.0 & 14901 & 1294-01 & 37632 & Eimen-Mainzholzen \\
\hline 1 & Seewind 20/110 & 110 & 20.0 & 15101 & $1307-01$ & 49685 & Hoheging \\
\hline 1 & AN Bonus 150/30 & 150 & 23.0 & 15201 & $1160-01$ & 31177 & Harsum \\
\hline 1 & Enercon E 40 & 500 & 40.3 & 15301 & $1301-01$ & 26897 & Hilkenbrook \\
\hline 1 & Südwind N 1237 & 37 & 12.5 & 15401 & $1279-01$ & 31718 & Pollhagen \\
\hline 1 & Nordex N 52/800 & 800 & 52.0 & 15501 & 1314-01 & 26826 & Weener \\
\hline 1 & AN Bonus 450/37 & 450 & 37.0 & 15601 & 1218-01 & 27632 & Padingbüttel \\
\hline 1 & Enercon E 40 & 500 & 40.3 & 15701 & $1293-02$ & 26506 & Norden-Westermarsch \\
\hline 1 & Vestas V 39/500 & 500 & 39.0 & 15801 & $1193-02$ & 26529 & Wirdum \\
\hline 1 & $\begin{array}{l}\text { Nordtank NTK } \\
500 / 41\end{array}$ & 500 & 41.0 & 15901 & $1305-01$ & 26759 & Hinte \\
\hline 1 & $\begin{array}{l}\text { Wind World W } \\
2700 / 150\end{array}$ & 150 & 27.0 & 16001 & $1245-01$ & 26506 & Norden-Westermarsch \\
\hline 1 & Tacke TW 500 & 500 & 37.0 & 16101 & $1250-01$ & 26506 & Norden-Ostermarsch \\
\hline 1 & Enercon E 30 & 200 & 30.0 & 16201 & $1316-01$ & 26506 & Norden-Norddeich \\
\hline 1 & GET 41 & 600 & 41.0 & 16301 & $1318-01$ & 26427 & Dunum-Brill \\
\hline 1 & Nordex N 27/250 & 250 & 27.0 & 16401 & $1170-01$ & 26506 & Norden-Westermarsch \\
\hline 1 & Vestas V 42/600 & 600 & 42.0 & 16601 & $1315-01$ & 26506 & Norden-Westermarsch \\
\hline 1 & $\begin{array}{l}\text { Euroturbine ET } \\
550 / 41\end{array}$ & 550 & 41.5 & 16701 & $1319-01$ & 21684 & Agathenburg \\
\hline 1 & AN Bonus 450/37 & 450 & 37.0 & 16901 & $1248-01$ & 26419 & Schortens \\
\hline 1 & GET 41 & 600 & 41.0 & 17001 & $1320-01$ & 26419 & Schortens-Sillenstede \\
\hline 1 & Enercon E 40 & 500 & 40.3 & 17101 & $1253-05$ & 26723 & Emden-Larrelt \\
\hline 1 & $\begin{array}{l}\text { Nordtank NTK } \\
500 / 37\end{array}$ & 500 & 37.0 & 17201 & $1282-01$ & 26553 & Nesse \\
\hline 1 & Enercon E 40 & 500 & 40.3 & 17301 & $1285-01$ & 26553 & Dornum \\
\hline 1 & AN Bonus 450/37 & 450 & 37.0 & 17401 & $1286-02$ & 26524 & Hagermarsch \\
\hline 1 & Enercon E 66 & 1500 & 66.0 & 17501 & $1323-01$ & 26723 & Emden \\
\hline 1 & AN Bonus 300/33 & 300 & 33.0 & 17601 & $1322-01$ & 31177 & Harsum-Machtsum \\
\hline 1 & AN Bonus 450/37 & 450 & 37.0 & 17701 & 1295-01 & 26427 & Neuharlingersiel \\
\hline 1 & Enercon E 40 & 500 & 40.3 & 17801 & $1296-01$ & 26434 & Wangerland-Grimmens \\
\hline 1 & Tacke TW 600 & 600 & 43.0 & 17901 & $1317-01$ & 26427 & Holtgast-Utgast \\
\hline
\end{tabular}




\begin{tabular}{|c|c|c|c|c|c|c|c|}
\hline 1 & Tacke TW 600 & 600 & 43.0 & 17902 & $1317-02$ & 26427 & Holtgast-Utgast \\
\hline 1 & AN Bonus 450/37 & 450 & 37.0 & 18001 & 1283-01 & 26427 & Utgast \\
\hline & $\begin{array}{l}\text { Nordtank NTK } \\
500 / 37\end{array}$ & 500 & 37.0 & 18101 & $1290-01$ & 26434 & $\begin{array}{l}\text { Wangerland-Wüppelser } \\
\text { Groden }\end{array}$ \\
\hline 1 & Adler 25 & 165 & 25.0 & 30101 & 0075-01 & 25693 & St. Michaelisdonn \\
\hline 1 & Vestas V 25/200 & 200 & 25.0 & 30201 & 0093-01 & 25849 & Pellworm \\
\hline 1 & Adler 25 & 165 & 25.0 & 30501 & 0086-02 & 23570 & Lübeck-Brodten \\
\hline 1 & HSW 250 & 250 & 25.0 & 30502 & 0086-03 & 23570 & Lübeck-Brodten \\
\hline 1 & HSW 250 & 250 & 25.0 & 30503 & 0086-01 & 23570 & Lübeck-Brodten \\
\hline 1 & Micon M 530-175 & 175 & 26.0 & 30601 & 0095-01 & 24229 & Strande \\
\hline 1 & Micon M 530-250/50 & 250 & 26.0 & 30701 & 0077-02 & 25764 & Schülp \\
\hline 1 & Micon M 530-250/50 & 250 & 26.0 & 30702 & $0077-01$ & 25764 & Schülp \\
\hline 1 & Vestas V 27/225 & 225 & 27.0 & 30801 & 0081-04 & 25938 & Oevenum/Föhr \\
\hline 1 & Vestas V 27/225 & 225 & 27.0 & 30802 & $0081-05$ & 25938 & Oevenum/Föhr \\
\hline 1 & Lagerwey LW 15/75 & 75 & 15.6 & 30901 & 0002-01 & 25599 & Wewelsfleth \\
\hline 1 & Vestas V 25/200 & 200 & 25.0 & 31001 & $0052-01$ & 24407 & Oersberg \\
\hline 1 & Tacke TW 250 & 250 & 24.0 & 31301 & 0039-01 & 23827 & Garbeck \\
\hline 1 & Vestas V 25/200 & 200 & 25.0 & 31401 & 0110-01 & 25856 & Hattstedtermarsch \\
\hline 1 & Vestas V 25/200 & 200 & 25.0 & 31501 & 0024-01 & 25826 & St. Peter-Ording \\
\hline 1 & Lagerwey LW 15/75 & 75 & 15.6 & 31601 & 0091-01 & 25899 & Niebüll \\
\hline 1 & Enercon E 32 & 300 & 33.0 & 31701 & 0034-01 & 25899 & Galmsbüll \\
\hline 1 & Vestas V 25/200 & 200 & 25.0 & 31801 & 0046-01 & 25842 & Ockholm \\
\hline 1 & Vestas V 25/200 & 200 & 25.0 & 31901 & $0035-01$ & 25899 & Dagebüll \\
\hline 1 & WTN 200/26 & 200 & 26.0 & 32001 & 0103-01 & 25554 & Sachsenbande \\
\hline 1 & $\begin{array}{l}\text { Wind World W } \\
2700 / 150\end{array}$ & 150 & 27.0 & 32101 & $0074-01$ & 25860 & Horstedt \\
\hline 1 & Vestas V 25/200 & 200 & 25.0 & 32201 & 0004-01 & 25885 & Immenstedt \\
\hline 1 & Vestas V 25/200 & 200 & 25.0 & 32301 & 0037-01 & 25873 & Oldersbek \\
\hline 1 & HSW 250 & 250 & 25.0 & 32401 & 0010-01 & 25927 & Aventoft \\
\hline 1 & HSW 30 & 30 & 12.5 & 32501 & $0007-01$ & 25870 & Oldenswort \\
\hline 1 & WTN 200/26 & 200 & 26.0 & 32601 & $0044-06$ & 25889 & Uelvesbüllkoog \\
\hline 1 & Enercon E 17 & 80 & 17.2 & 32701 & 0078-01 & 23858 & Reinfeld \\
\hline 1 & Vestas V 25/200 & 200 & 25.0 & 32801 & 0019-01 & 25821 & Sönnebüll \\
\hline 1 & Enercon E 32 & 300 & 33.0 & 32901 & 0076-03 & 23769 & Petersdorf/Fehmarn \\
\hline 1 & Enercon E 32 & 300 & 33.0 & 33101 & $0089-02$ & 23769 & $\begin{array}{l}\text { Westermarkelsdorf/Feh } \\
\text { marn }\end{array}$ \\
\hline 1 & $\begin{array}{l}\text { Wind World W } \\
2700 / 150\end{array}$ & 150 & 27.0 & 33201 & $0088-01$ & 23769 & Klausdorf/Fehmarn \\
\hline 1 & Micon M 530-250/50 & 250 & 26.0 & 33301 & 0083-01 & 25862 & Joldelund \\
\hline 1 & Enercon E 17 & 80 & 19.4 & 33401 & 0097-01 & 24872 & Groß Rheide \\
\hline 1 & Vestas V 17/75 & 75 & 17.0 & 33501 & 0003-01 & 24879 & Neuberend \\
\hline 1 & Krogmann 15/50 & 50 & 15.0 & 33601 & 0043-01 & 23730 & Schashagen \\
\hline 1 & AN Bonus 150/30 & 150 & 23.0 & 33801 & 0060-01 & 23779 & Neukirchen \\
\hline 1 & AN Bonus 100/30 & 100 & 23.0 & 33901 & 0020-01 & 22880 & Wedel \\
\hline 1 & Enercon E 17 & 80 & 17.2 & 34001 & 0023-01 & 24894 & Twedt \\
\hline 1 & Micon M 530-250/50 & 250 & 26.0 & 34101 & 0100-01 & 25821 & Reußenköge \\
\hline 1 & Vestas V 25/200 & 200 & 25.0 & 34201 & 0061-03 & 23769 & $\begin{array}{l}\text { Westermarkelsdorf/Feh } \\
\text { marn }\end{array}$ \\
\hline
\end{tabular}




\begin{tabular}{|c|c|c|c|c|c|c|c|}
\hline 1 & Vestas V 25/200 & 200 & 25.0 & 34202 & $0061-02$ & 23769 & $\begin{array}{l}\text { Westermarkelsdorf/Feh } \\
\text { marn }\end{array}$ \\
\hline 1 & $\begin{array}{l}\text { Nordtank NTK } 150 \\
\text { XLR }\end{array}$ & 150 & 24.6 & 34401 & $0050-01$ & 24881 & Breklingfeld \\
\hline 1 & HSW 30 & 30 & 12.5 & 34601 & $0115-01$ & 24407 & Kragelund \\
\hline 1 & Südwind N 1230 & 30 & 12.5 & 34701 & $3000-01$ & 21129 & Hamburg-Nincop \\
\hline 1 & HSW $250 \mathrm{~T}$ & 250 & 28.5 & 34801 & 0109-04 & 25845 & Nordstrand \\
\hline 1 & HSW $250 \mathrm{~T}$ & 250 & 28.5 & 34802 & 0109-05 & 25845 & Nordstrand \\
\hline 1 & Vestas V 25/200 & 200 & 25.0 & 34901 & 0006-01 & 25746 & Norderwöhrden \\
\hline 1 & Nordex N 27/250 & 250 & 27.0 & 35001 & 0141-01 & 25541 & Brunsbüttel \\
\hline 1 & Nordex N 27/150 & 150 & 27.0 & 35101 & 0167-01 & 25599 & Wewelsfleth \\
\hline 1 & $\begin{array}{l}\text { Nordtank NTK } 150 \\
\text { XLR }\end{array}$ & 150 & 24.6 & 35201 & 0064-01 & 25872 & Ostenfeld \\
\hline 1 & $\begin{array}{l}\text { Nordtank NTK } \\
300 / 31\end{array}$ & 300 & 31.0 & 35301 & $0137-03$ & 25845 & Nordstrand \\
\hline 1 & Enercon E 18 & 80 & 19.4 & 35401 & 0123-01 & 24647 & Wasbek \\
\hline 1 & WTN 200/26 & 200 & 26.0 & 35601 & $0127-05$ & 25899 & Galmsbüll \\
\hline 1 & WTN 200/26 & 200 & 26.0 & 35602 & 0127-06 & 25899 & Galmsbüll \\
\hline 1 & Tacke TW 500 & 500 & 37.0 & 35801 & $0211-02$ & 25764 & Schülp \\
\hline 1 & Tacke TW 600 & 600 & 43.0 & 35802 & $0211-03$ & 25764 & Schülp \\
\hline 1 & Vestas V 20/100 & 110 & 20.0 & 35901 & 0197-01 & 24999 & Wees-Oxbüll \\
\hline 1 & Südwind N 1230 & 30 & 12.5 & 36001 & 0105-01 & 24253 & Passade \\
\hline 1 & AN Bonus 150/30 & 150 & 23.0 & 36101 & $0165-01$ & 24220 & Boksee \\
\hline 1 & Südwind N 3127 & 270 & 31.0 & 36201 & 0228-01 & 24940 & Goosefeld \\
\hline 1 & Tacke TW 250 & 250 & 24.0 & 36301 & 0114-01 & 24819 & Nienborstel \\
\hline 1 & Kano-Rotor 30 & 30 & 12.1 & 36401 & 0102-01 & 25779 & Glüsing \\
\hline 1 & Enercon E 32 & 300 & 33.0 & 36501 & 0159-01 & 24994 & Jardelund \\
\hline 1 & $\begin{array}{l}\text { Micon M 750- } \\
400 / 100\end{array}$ & 400 & 31.0 & 36601 & 0187-09 & 25821 & Reußenköge \\
\hline 1 & Enercon E 40 & 500 & 40.3 & 36602 & 0187-07 & 25821 & Reußenköge \\
\hline 1 & $\begin{array}{l}\text { Micon M 1500- } \\
600 / 150\end{array}$ & 600 & 43.4 & 36701 & $0213-03$ & 24969 & Lindewitt \\
\hline 1 & AN Bonus $600 / 44-2$ & 600 & 44.0 & 36801 & $3012-01$ & 21039 & Hamburg-Altengamme \\
\hline 1 & GET 41 & 600 & 41.0 & 36901 & 0238-01 & 25541 & Brunsbüttel \\
\hline 1 & GET Danwin 27 & 225 & 29.1 & 36902 & 0238-05 & 25541 & Brunsbüttel \\
\hline 1 & HSW 1000/54 & 1000 & 54.0 & 37001 & $0237-01$ & 25899 & Bosbüll \\
\hline 1 & Jacobs $41 / 500$ & 500 & 41.0 & 37101 & 0239-01 & 25693 & Trennewurth \\
\hline 1 & Jacobs $43 / 600$ & 600 & 43.0 & 37201 & 0240-01 & 25797 & Wöhrden-Neuenkrug \\
\hline 1 & Jacobs $41 / 500$ & 500 & 41.0 & 37301 & $0245-01$ & 25718 & $\begin{array}{l}\text { Friedrichskoog- } \\
\text { Dieksanderkoog }\end{array}$ \\
\hline 1 & Vestas V 63/1.5 & 1500 & 63.0 & 37401 & $0151-06$ & 25709 & Kaiser-Wilhelm-Koog \\
\hline 1 & $\begin{array}{l}\text { Nordtank NTK } 150 \\
\text { XLR }\end{array}$ & 150 & 24.6 & 50201 & $7507-01$ & 18233 & Rakow \\
\hline 1 & $\begin{array}{l}\text { Nordtank NTK } 150 \\
\text { XLR }\end{array}$ & 150 & 24.6 & 50202 & $7507-02$ & 18233 & Rakow \\
\hline 1 & Südwind N 1237 & 37 & 12.5 & 50401 & $7508-01$ & 23974 & Zarnekow \\
\hline 1 & Enercon E 33 & 300 & 33.0 & 50501 & $7502-01$ & 18556 & Altenkirchen/Rügen \\
\hline 1 & Enercon E 33 & 300 & 33.0 & 50502 & $7502-02$ & 18556 & Altenkirchen/Rügen \\
\hline
\end{tabular}




\begin{tabular}{|c|c|c|c|c|c|c|c|}
\hline 1 & Enercon E 33 & 300 & 33.0 & 50701 & $8500-01$ & 16928 & Rapshagen \\
\hline 1 & Micon M 570-200/40 & 200 & 27.0 & 50801 & $8000-01$ & 7554 & Söllmnitz \\
\hline 1 & Lagerwey LW 15/75 & 75 & 15.6 & 50901 & $7506-01$ & 23936 & Diedrichshagen \\
\hline 1 & Enercon E 40 & 500 & 40.3 & 51201 & 7008-01 & 2708 & Laucha \\
\hline 1 & Enercon E 32 & 300 & 33.0 & 51401 & $7520-01$ & 18311 & Ribnitz-Körkwitz \\
\hline 1 & Micon M 530-250/50 & 250 & 26.0 & 51501 & $7524-02$ & 18356 & Küstrow \\
\hline 1 & $\begin{array}{l}\text { Nordtank NTK } \\
300 / 31\end{array}$ & 300 & 31.0 & 51502 & $7524-01$ & 18356 & Küstrow \\
\hline 1 & Micon M 530-250/50 & 250 & 26.0 & 51503 & 7524-03 & 18356 & Küstrow \\
\hline 1 & Micon M 530-250/50 & 250 & 26.0 & 51504 & $7524-04$ & 18356 & Küstrow \\
\hline 1 & Enercon E 33 & 300 & 33.0 & 51505 & $7524-06$ & 18356 & Küstrow \\
\hline 1 & WTN 200/26 & 200 & 26.0 & 51601 & $8501-01$ & 17291 & Schmölln \\
\hline 1 & WTN 200/26 & 200 & 26.0 & 51602 & $8501-02$ & 17291 & Schmölln \\
\hline 1 & WTN 200/26 & 200 & 26.0 & 51603 & $8501-03$ & 17291 & Schmölln \\
\hline 1 & AN Bonus 450/37 & 450 & 37.0 & 51701 & $7530-03$ & 18573 & Rambin \\
\hline 1 & AN Bonus 150/30 & 150 & 23.0 & 51702 & $7530-01$ & 18573 & Rambin \\
\hline 1 & $\begin{array}{l}\text { Nordtank NTK } \\
300 / 31\end{array}$ & 300 & 31.0 & 51801 & $7519-01$ & 18375 & Born am Darß \\
\hline 1 & $\begin{array}{l}\text { Nordtank NTK } \\
300 / 31\end{array}$ & 300 & 31.0 & 51802 & $7519-02$ & 18375 & Born am Darß \\
\hline 1 & Lagerwey LW 18/80 & 80 & 18.0 & 51901 & $7526-02$ & 18356 & Fuhlendorf \\
\hline 1 & Lagerwey LW 15/75 & 75 & 15.6 & 51902 & $7526-01$ & 18356 & Fuhlendorf \\
\hline 1 & Lagerwey LW 15/75 & 75 & 15.6 & 51903 & 7526-03 & 18356 & Fuhlendorf \\
\hline 1 & $\begin{array}{l}\text { Nordtank NTK } \\
500 / 41\end{array}$ & 500 & 41.0 & 52001 & $7557-02$ & 17509 & Wusterhusen \\
\hline 1 & $\begin{array}{l}\text { Nordtank NTK } \\
500 / 41\end{array}$ & 500 & 41.0 & 52002 & $7557-01$ & 17509 & Wusterhusen \\
\hline 1 & $\begin{array}{l}\text { Lagerwey LW } \\
30 / 250\end{array}$ & 250 & 30.0 & 52201 & $8017-01$ & 99510 & Wormstedt \\
\hline 1 & $\begin{array}{l}\text { Wind World W } \\
4100 / 500\end{array}$ & 500 & 41.0 & 52202 & $8017-02$ & 99510 & Wormstedt \\
\hline 1 & NedWind 44 & 500 & 43.8 & 52203 & $8017-03$ & 99510 & Wormstedt \\
\hline 1 & $\begin{array}{l}\text { Euroturbine ET } \\
550 / 41\end{array}$ & 550 & 41.5 & 52301 & $7563-01$ & 18356 & Barth \\
\hline 1 & Enercon E 40 & 500 & 40.3 & 52501 & 7533-01 & 18556 & Altenkirchen/Rügen \\
\hline 1 & Micon M 700-225/40 & 225 & 29.6 & 52601 & $8009-01$ & 37308 & Reinholterode \\
\hline 1 & Tacke TW 300 & 300 & 33.0 & 52602 & $8009-02$ & 37308 & Reinholterode \\
\hline 2 & Enercon E 32 & 300 & 32.0 & 10005 & $1011-05$ & 26506 & Norden-Ostermarsch \\
\hline 2 & Enercon E 33 & 300 & 33.0 & 10006 & $1011-06$ & 26506 & Norden-Ostermarsch \\
\hline 2 & Enercon E 40 & 500 & 40.3 & 15701 & $1293-02$ & 26506 & Norden-Westermarsch \\
\hline 2 & $\begin{array}{l}\text { Wind World W } \\
2700 / 150\end{array}$ & 150 & 27.0 & 16001 & $1245-01$ & 26506 & Norden-Westermarsch \\
\hline 2 & Tacke TW 500 & 500 & 37.0 & 16101 & $1250-01$ & 26506 & Norden-Ostermarsch \\
\hline 2 & Enercon E 30 & 200 & 30.0 & 16201 & $1316-01$ & 26506 & Norden-Norddeich \\
\hline 2 & Nordex N 27/250 & 250 & 27.0 & 16401 & $1170-01$ & 26506 & Norden-Westermarsch \\
\hline
\end{tabular}




\begin{tabular}{|c|c|c|c|c|c|c|c|}
\hline 2 & Vestas V 42/600 & 600 & 42.0 & 16601 & $1315-01$ & 26506 & Norden-Westermarsch \\
\hline 2 & Lagerwey LW 15/75 & 75 & 15.6 & 31601 & $0091-01$ & 25899 & Niebüll \\
\hline 2 & Enercon E 32 & 300 & 33.0 & 31701 & 0034-01 & 25899 & Galmsbüll \\
\hline 2 & WTN 200/26 & 200 & 26.0 & 35601 & $0127-05$ & 25899 & Galmsbüll \\
\hline 2 & WTN 200/26 & 200 & 26.0 & 35602 & $0127-06$ & 25899 & Galmsbüll \\
\hline 2 & Micon M 530-250/50 & 250 & 26.0 & 51501 & $7524-02$ & 18356 & Küstrow \\
\hline 2 & $\begin{array}{l}\text { Nordtank NTK } \\
300 / 31\end{array}$ & 300 & 31.0 & 51502 & $7524-01$ & 18356 & Küstrow \\
\hline 2 & Micon M 530-250/50 & 250 & 26.0 & 51504 & 7524-04 & 18356 & Küstrow \\
\hline 2 & Enercon E 33 & 300 & 33.0 & 51505 & $7524-06$ & 18356 & Küstrow \\
\hline 2 & $\begin{array}{l}\text { Euroturbine ET } \\
550 / 41\end{array}$ & 550 & 41.5 & 52301 & $7563-01$ & 18356 & Barth \\
\hline 3 & Enercon E 32 & 300 & 32.0 & 10005 & $1011-05$ & 26506 & Norden-Ostermarsch \\
\hline 3 & Enercon E 33 & 300 & 33.0 & 10006 & $1011-06$ & 26506 & Norden-Ostermarsch \\
\hline 3 & Enercon E 17 & 80 & 19.4 & 13601 & $1050-01$ & 26506 & Norden-Süderneuland \\
\hline 3 & Enercon E 40 & 500 & 40.3 & 15701 & $1293-02$ & 26506 & Norden-Westermarsch \\
\hline 3 & $\begin{array}{l}\text { Wind World W } \\
2700 / 150\end{array}$ & 150 & 27.0 & 16001 & $1245-01$ & 26506 & Norden-Westermarsch \\
\hline 3 & Tacke TW 500 & 500 & 37.0 & 16101 & $1250-01$ & 26506 & Norden-Ostermarsch \\
\hline 3 & Enercon E 30 & 200 & 30.0 & 16201 & $1316-01$ & 26506 & Norden-Norddeich \\
\hline 3 & Nordex N 27/250 & 250 & 27.0 & 16401 & $1170-01$ & 26506 & Norden-Westermarsch \\
\hline 3 & Vestas V 42/600 & 600 & 42.0 & 16601 & $1315-01$ & 26506 & Norden-Westermarsch \\
\hline 3 & $\begin{array}{l}\text { Nordtank NTK } \\
500 / 37\end{array}$ & 500 & 37.0 & 17201 & $1282-01$ & 26553 & Nesse \\
\hline 3 & Enercon E 40 & 500 & 40.3 & 17301 & $1285-01$ & 26553 & Dornum \\
\hline 3 & AN Bonus 450/37 & 450 & 37.0 & 17401 & $1286-02$ & 26524 & Hagermarsch \\
\hline 3 & Tacke TW 600 & 600 & 43.0 & 17901 & $1317-01$ & 26427 & Holtgast-Utgast \\
\hline 3 & Tacke TW 600 & 600 & 43.0 & 17902 & 1317-02 & 26427 & Holtgast-Utgast \\
\hline 3 & AN Bonus 450/37 & 450 & 37.0 & 18001 & 1283-01 & 26427 & Utgast \\
\hline 4 & Enercon E 17 & 80 & 19.4 & 13601 & $1050-01$ & 26506 & Norden-Süderneuland \\
\hline 4 & $\begin{array}{l}\text { Wind World W } \\
2700 / 150\end{array}$ & 150 & 27.0 & 16001 & $1245-01$ & 26506 & Norden-Westermarsch \\
\hline 4 & Tacke TW 500 & 500 & 37.0 & 16101 & $1250-01$ & 26506 & Norden-Ostermarsch \\
\hline 4 & Enercon E 30 & 200 & 30.0 & 16201 & $1316-01$ & 26506 & Norden-Norddeich \\
\hline 4 & Vestas V 42/600 & 600 & 42.0 & 16601 & $1315-01$ & 26506 & Norden-Westermarsch \\
\hline 4 & Enercon E 40 & 500 & 40.3 & 17301 & $1285-01$ & 26553 & Dornum \\
\hline 4 & AN Bonus 450/37 & 450 & 37.0 & 17401 & $1286-02$ & 26524 & Hagermarsch \\
\hline 4 & AN Bonus 450/37 & 450 & 37.0 & 18001 & 1283-01 & 26427 & Utgast \\
\hline 5 & Enercon E 33 & 300 & 33.0 & 10006 & 1011-06 & 26506 & Norden-Ostermarsch \\
\hline 5 & Tacke TW 500 & 500 & 37.0 & 16101 & $1250-01$ & 26506 & Norden-Ostermarsch \\
\hline 5 & Enercon E 30 & 200 & 30.0 & 16201 & $1316-01$ & 26506 & Norden-Norddeich \\
\hline
\end{tabular}




\begin{tabular}{|c|c|c|c|c|c|c|c|}
\hline & $\begin{array}{l}\text { Nordtank NTK } \\
500 / 37\end{array}$ & 500 & 37.0 & 17201 & $1282-01$ & 26553 & Nesse \\
\hline 5 & Enercon E 40 & 500 & 40.3 & 17301 & $1285-01$ & 26553 & Dornum \\
\hline 5 & AN Bonus 450/37 & 450 & 37.0 & 17401 & 1286-02 & 26524 & Hagermarsch \\
\hline 5 & Tacke TW 600 & 600 & 43.0 & 17902 & $1317-02$ & 26427 & Holtgast-Utgast \\
\hline 5 & AN Bonus 450/37 & 450 & 37.0 & 18001 & $1283-01$ & 26427 & Utgast \\
\hline 6 & Enercon E 33 & 300 & 33.0 & 10006 & $1011-06$ & 26506 & Norden-Ostermarsch \\
\hline 6 & Tacke TW 500 & 500 & 37.0 & 16101 & $1250-01$ & 26506 & Norden-Ostermarsch \\
\hline 6 & $\begin{array}{l}\text { Nordtank NTK } \\
500 / 37\end{array}$ & 500 & 37.0 & 17201 & $1282-01$ & 26553 & Nesse \\
\hline 6 & Enercon E 40 & 500 & 40.3 & 17301 & $1285-01$ & 26553 & Dornum \\
\hline 6 & AN Bonus 450/37 & 450 & 37.0 & 17401 & 1286-02 & 26524 & Hagermarsch \\
\hline 6 & Tacke TW 600 & 600 & 43.0 & 17901 & $1317-01$ & 26427 & Holtgast-Utgast \\
\hline 6 & Tacke TW 600 & 600 & 43.0 & 17902 & $1317-02$ & 26427 & Holtgast-Utgast \\
\hline 6 & AN Bonus 450/37 & 450 & 37.0 & 18001 & 1283-01 & 26427 & Utgast \\
\hline 7 & Enercon E 33 & 300 & 33.0 & 10006 & $1011-06$ & 26506 & Norden-Ostermarsch \\
\hline 7 & Enercon E 17 & 80 & 19.4 & 13601 & $1050-01$ & 26506 & Norden-Süderneuland \\
\hline 7 & Enercon E 40 & 500 & 40.3 & 15701 & $1293-02$ & 26506 & Norden-Westermarsch \\
\hline 7 & $\begin{array}{l}\text { Wind World W } \\
2700 / 150\end{array}$ & 150 & 27.0 & 16001 & $1245-01$ & 26506 & Norden-Westermarsch \\
\hline 7 & Tacke TW 500 & 500 & 37.0 & 16101 & $1250-01$ & 26506 & Norden-Ostermarsch \\
\hline 7 & Enercon E 30 & 200 & 30.0 & 16201 & $1316-01$ & 26506 & Norden-Norddeich \\
\hline 7 & Nordex N 27/250 & 250 & 27.0 & 16401 & $1170-01$ & 26506 & Norden-Westermarsch \\
\hline 7 & Vestas V 42/600 & 600 & 42.0 & 16601 & $1315-01$ & 26506 & Norden-Westermarsch \\
\hline 8 & Enercon E 32 & 300 & 32.0 & 10005 & $1011-05$ & 26506 & Norden-Ostermarsch \\
\hline 8 & Enercon E 33 & 300 & 33.0 & 10006 & $1011-06$ & 26506 & Norden-Ostermarsch \\
\hline 8 & Enercon E 40 & 500 & 40.3 & 15701 & $1293-02$ & 26506 & Norden-Westermarsch \\
\hline 8 & $\begin{array}{l}\text { Wind World W } \\
2700 / 150\end{array}$ & 150 & 27.0 & 16001 & $1245-01$ & 26506 & Norden-Westermarsch \\
\hline 8 & Tacke TW 500 & 500 & 37.0 & 16101 & $1250-01$ & 26506 & Norden-Ostermarsch \\
\hline 8 & Enercon E 30 & 200 & 30.0 & 16201 & $1316-01$ & 26506 & Norden-Norddeich \\
\hline 8 & Nordex N 27/250 & 250 & 27.0 & 16401 & $1170-01$ & 26506 & Norden-Westermarsch \\
\hline 8 & Vestas V 42/600 & 600 & 42.0 & 16601 & $1315-01$ & 26506 & Norden-Westermarsch \\
\hline
\end{tabular}




\section{Appendix B}

Table 2. Turbines of site 1

\begin{tabular}{|l|l|l|l|l|l|r|l|}
\hline Number & Type & $\begin{array}{l}\text { Rated } \\
\text { Power }\end{array}$ & $\begin{array}{l}\text { Rotor } \\
\text { Diameter }\end{array}$ & $\begin{array}{l}\text { Data } \\
\text { Logger } \\
\text { No. }\end{array}$ & WMEP No. & Zip Code & City \\
\hline 1 & Nordtank NTK 300/31 & 300 & 31 & 51502 & $7524-01$ & 18356 Küstrow \\
\hline 2 & Micon M 530-250/50 & 250 & 26 & 51501 & $7524-02$ & 18356 Küstrow \\
\hline 3 & Micon M 530-250/50 & 250 & 26 & 51503 & $7524-03$ & 18356 Küstrow \\
\hline 4 & Micon M 530-250/50 & 250 & 26 & 51504 & $7524-04$ & 18356 Küstrow \\
\hline 5 & Enercon E 33 & 300 & 33 & 51505 & $7524-06$ & 18356 Küstrow \\
\hline 6 & Lagerwey LW 15/75 & 75 & 15.6 & 51903 & $7526-03$ & 18356 Fuhlendorf \\
\hline 7 & Lagerwey LW 18/80 & 80 & 18 & 51901 & $7526-02$ & 18356 Fuhlendorf \\
\hline 8 & Lagerwey LW 15/75 & 75 & 15.6 & 51902 & $7526-01$ & 18356 Fuhlendorf \\
\hline
\end{tabular}

Table 3. Turbines of site 2

\begin{tabular}{|l|l|l|l|l|l|r|l|}
\hline Number & Type & $\begin{array}{l}\text { Rated } \\
\text { Power }\end{array}$ & $\begin{array}{l}\text { Rotor } \\
\text { Diameter }\end{array}$ & $\begin{array}{l}\text { Data } \\
\text { Logger } \\
\text { No. }\end{array}$ & $\begin{array}{l}\text { WMEP } \\
\text { No. }\end{array}$ & $\begin{array}{r}\text { Zip } \\
\text { Code }\end{array}$ & City \\
\hline 1 & Enercon E 32 & 300 & 32 & 10005 & $1011-05$ & 26506 & Norden-Ostermarsch \\
\hline 2 & Enercon E 33 & 300 & 33 & 10006 & $1011-06$ & 26506 & Norden-Ostermarsch \\
\hline 3 & Enercon E 30 & 200 & 30 & 16201 & $1316-01$ & 26506 & Norden-Norddeich \\
\hline 4 & Tacke TW 500 & 500 & 37 & 16101 & $1250-01$ & 26506 & Norden-Ostermarsch \\
\hline
\end{tabular}




\section{Bibliography}

Beyer, Hans Georg; Waldl, Hans-Peter. (1995). Modellierung des Leistungsverhaltens von Windparks. Abschlussbericht. Oldenburg: Fachbereich Physik, Universität Oldenburg.

Hirst, Eric; Kirby, Brendan. (December 1996). "Costs For Electric-Power Ancillary Services.” The Electricity Journal; pp. 26-30.

Institut für Solare Energieversorgungstechnik e.V., Querschnitts-Projektbereich Windenergie. (1998). Wissenschaftliches Meß- und Evaluierungsprogramm (WMEP) zum Breitentest "250 MW Wind", Jahresauswertung 1997. Kassel.

Molly, Jens-Peter. (1990). Windenergie: Theorie, Anwendung, Messung. 2nd edition. Karlsruhe, Germany: C.F. Muller.

Press, William H.; Teukolsky, Saul A.; Vetterling, William T.; Flannery, Brian P. (1992). Numerical Recipies in C. 2nd edition. Cambridge University Press.

Singh, H. (1999). Auctions for Ancillary Services. Decision Support Systems, Vol. 24, Issue 3-4, pp. 173336, January, pp. 183-191. 


\section{REPORT DOCUMENTATION PAGE}

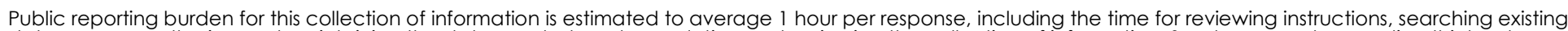

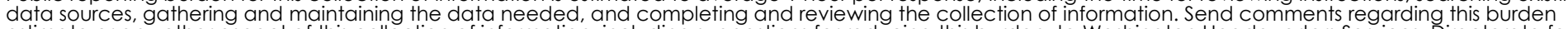

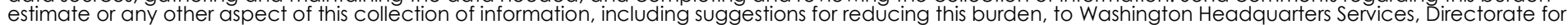

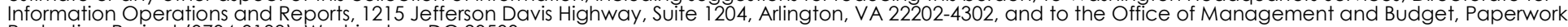
Reduction Project (0704-0188), Washington, DC 20503.

\begin{tabular}{l|l|l} 
1. AGENCY USE ONLY (Leave blank) & $\begin{array}{l}\text { 2. REPORT DATE } \\
\text { November } 1999\end{array}$ & $\begin{array}{l}\text { 3. REPORT TYPE AND DATES COVERED } \\
\text { Technical Report }\end{array}$
\end{tabular}

4. TITLE AND SUBTITLE

Analysis of Wind Power Ancillary Services Characteristics with German 250-MW Wind Data

5. FUNDING NUMBERS WE003010

6. AUTHOR(S) Bernhard Ernst

7. PERFORMING ORGANIZATION NAME(S) AND ADDRESS(ES)

National Renewable Energy Laboratory

1617 Cole Blvd.

Golden, Colorado 80401-3393

8. PERFORMING ORGANIZATION REPORT NUMBER

TP-500-26969

9. SPONSORING/MONITORING AGENCY NAME(S) AND ADDRESS(ES)

National Renewable Energy Laboratory

10. SPONSORING/MONITORING AGENCY REPORT NUMBER

1617 Cole Blvd.

Golden, CO 80401-3393

11. SUPPLEMENTARY NOTES

NREL Technical Monitor:

12a. DISTRIBUTION/AVAILABILITY STATEMENT

National Technical Information Service

2b. DISTRIBUTION CODE

U.S. Department of Commerce

5285 Port Royal Road

Springfield, VA 22161

13. ABSTRACT (Maximum 200 words) With the increasing availability of wind power worldwide, power fluctuations have become a concern for some utilities. Under electric industry restructuring in the United States, the impact of these fluctuations will be evaluated by examining provisions and costs of ancillary services for wind power. This paper analyzes wind power in the context of ancillary services, using data from a German 250 Megawatt Wind project.

\begin{tabular}{|c|c|c|c|}
\hline \multirow{2}{*}{ 14. SUBJECT TERMS } & & & 15. NUMBER OF PAGES \\
\hline & & & 16. PRICE CODE \\
\hline $\begin{array}{l}\text { 17. SECURITY CLASSIFICATION } \\
\text { OF REPORT } \\
\text { Unclassified }\end{array}$ & $\begin{array}{l}\text { 18. SECURITY CLASSIFICATION } \\
\text { OF THIS PAGE } \\
\text { Unclassified }\end{array}$ & $\begin{array}{l}\text { 19. SECURITY CLASSIFICATION } \\
\text { OF ABSTRACT } \\
\text { Unclassified }\end{array}$ & $\begin{array}{l}\text { 20. LIMITATION OF ABSTRACT } \\
\text { UL }\end{array}$ \\
\hline
\end{tabular}

NSN 7540-01-280-5500

Standard Form 298 (Rev. 2-89) Prescribed by ANSI Std. Z39-18 